\title{
Some Results of the International Fishery Investigations.
}

By

Jas. Johnstone.

IT is always an unsatisfactory task to attempt to summarize the results of an extensive piece of scientific work while this is still in progress. The conclusions made during the course of a series of researches are necessarily tentative ones, and subject to more or less modification when the work comes to an end. Even the main facts elicited during the investigation do not at the time present themselves in their real proportions. One fails to appreciate the importance of some, and may be tempted to give emphasis to others which do not possess the significance assigned to them. Such considerations apply with special force to the following sketch of the main results apparent so far from the work of the International Fishery Investigations in the Northern European seas. Nine countries_Britain, Belgium, Denmark, Germany, Finland, The Netherlands, Norway, Russia, and Sweden-are engaged in these researches. Each country has its own staff of scientific men (and women); its own exploring vessels and laboratories; and its own publications.* Controlling and supervising all this work is the International Council, operating through the Bureau at Copenhagen, and the Central Laboratory at Christiania.

Common plans and programmes of work were arranged by the Council at the outset of the investigations and at various times since then; but while this is the case, each country is still at liberty to "fight for its own hand." It will easily be seen then that the co-ordination of the

* For the English reader the following are the most important publications :-

The Rapports et Proces-verbaux of the Council, especially vol. iii.

The English Blue books. Fishery and Hydrographic Investigations in the North Sea and adjacent regions (ed. 2612, 1905; and ed. 2670, 1905). North Sea Fishery Investigations, Reports and Correspondence, vol. i. (cd. 2966, 1905). (Vol. ii. of this Blue book is identical with Rapports et Procès-verbaux, vol. iii.)

The Bulletin des Resultats of the Council.

The Publications de Circonstance of the Council.

The Danish Meddelelser fra Kommissionen for Havundensögelser (in English).

The German Beteiligung Deutschlands an den Internationalen Meeresforschung.

The Journal of the Marine Biological Association.

There are of course other publications, but the above are the most noteworthy and generally interesting.

NEW SERIES. VOL, VII. NO. 5. OCTOBER, 1906.

$2 \mathrm{G}$ 
numerous researches, and the discussion of the results obtained in relation to each other, must be a task of considerable difficulty, and indeed cannot properly be undertaken until the conclusion of the series of investigations. It is most necessary that the reader should bear this in mind in following the present account of the International Fishery Investigations.

The International Fishery researches fall under three main categories: (1) the hydrographic work, which deals with physical investigation on the constitution and movements of the water in our northern seas; (2) the purely biological work both strictly zoological and bionomical; and (3) fishery investigations consisting of the fishery experiments involving the use of commercial and research fishing gear, and of statistical studies. I will take these main lines of research in the above order.

\section{The Hydrographical Investigations.}

I think it necessary to give a very short account of the topography of the sea bottom in the area under investigation, though our knowledge of this was obtained previous to the inception of the International Fisheries work, and has not been materially changed in the course of this. It is well known that the British Isles are situated on a submarine plateau which forms part of the European "Continental Shelf." If an imaginary line be drawn in this area so as to connect all points where the sea is 100 fathoms in depth, it will be found that the British Islands are included within it. Such a line will enclose an area which includes a considerable portion of the Atlantic to the west of Ireland and Scotland, the Irish Sea, the English Channel, and the North Sea with the exception of a deep depression which skirts the coasts of Norway and Sweden. Over the greater part of this area the sea is less than 300 feet in depth, and with the exception of two or three isolated "deeps" is everywhere less than 600 feet in depth.

From the north of Scotland, and extending in a north-westerly direction, is a submarine ridge which connects together the British submarine plateau with the plateaux on which are situated the Faeroe Isles and Iceland. Between Greenland and Iceland, and between Iceland and the Faeroe Isles, are extensive banks over which the sea is from 200 to 300 fathoms in depth. Then joining the Faeroes to the British plateau is a narrow ridge-the Wyville-Thomson Ridge. To the north-east of this ridge the sea bottom rapidly sinks down, forming a channel of over 500 fathoms in depth, deepening to form the Norwegian sea, with a maximum depth of nearly 2000 fathoms. On the south-west side of the ridge the sea bottom as rapidly sinks down into the abysses of the Atlantic Ocean. The Wyville-Thomson Ridge 
forms the "watershed" between two deep-water basins differing conspicuously from each other. On the top of the ridge the water may have a bottom temperature of $2^{\circ} \mathrm{C}$. On the southern slopes it is washed by water with a relatively high temperature, $6^{\circ} \mathrm{C}$. to $10^{\circ} \mathrm{C}$., and even down to a depth of 700 metres the temperature may be as high as $6^{\circ}$. On the other hand, the temperature falls rapidly as we descend the northern slopes towards the Norwegian sea, until we find in the deeps of the latter a mass of sea water the temperature of which is, with one exception, lower than anywhere else in the oceans of the earth. In the deepest part of the Norwegian sea the temperature of the water is $1^{\circ} \cdot 3 \mathrm{C}$. below the freezing point of fresh water.

Over practically the whole of the British and North Sea plateau, on the Norwegian coastal banks, the Faeroese and Icelandic banks, the Baltic and the coastal banks in the Barentz Sea, commercial fishing is carried on. Though the tendency is always for the extension of trawl and line fishing into deeper water, yet the greater part of the Norwegian sea is not fished over. Still this extensive area is most interesting from the point of view of the investigator, and many fishing experiments have been made therein.

This then is the nature of the area over which the International Fishery Investigations are being carried on. The accompanying Chart (Fig. 1) shows how it has been divided up so as to apportion the work between the various countries participating in the scheme of research.

Hydrographic investigations have for their aim the determination of the physical characters of the sea water in the different regions of the extensive area mentioned above. The physical characters to which I allude are: (1) the temperature; (2) the salinity, that is, the weight of solid saline matter contained in 1000 grammes of sea water; and (3) the nature and abundance of the gases (oxygen, nitrogen, carbonic acid, sulphuretted hydrogen, etc.) dissolved in it. Other characters are from time to time of importance, but the hydrographic condition of any portion of sea water is usually defined by its temperature and salinity, and the determination of these are the essentials of marine hydrographic research. Not only do these characters, vary from time to time in the same region-both temperature and salinity are, for instance, different in the water covering the Dogger Bank in winter and summer-but they may vary with the locality. The water on the Dogger may be physically very different from that present in the Faeroe-Shetland channel or in the Cattegat. The determination, then, of both temperature and salinity, simultaneously over the whole area, at periodical times, is the obligatory hydrographic work at present carried on by the International Fishery organization. 


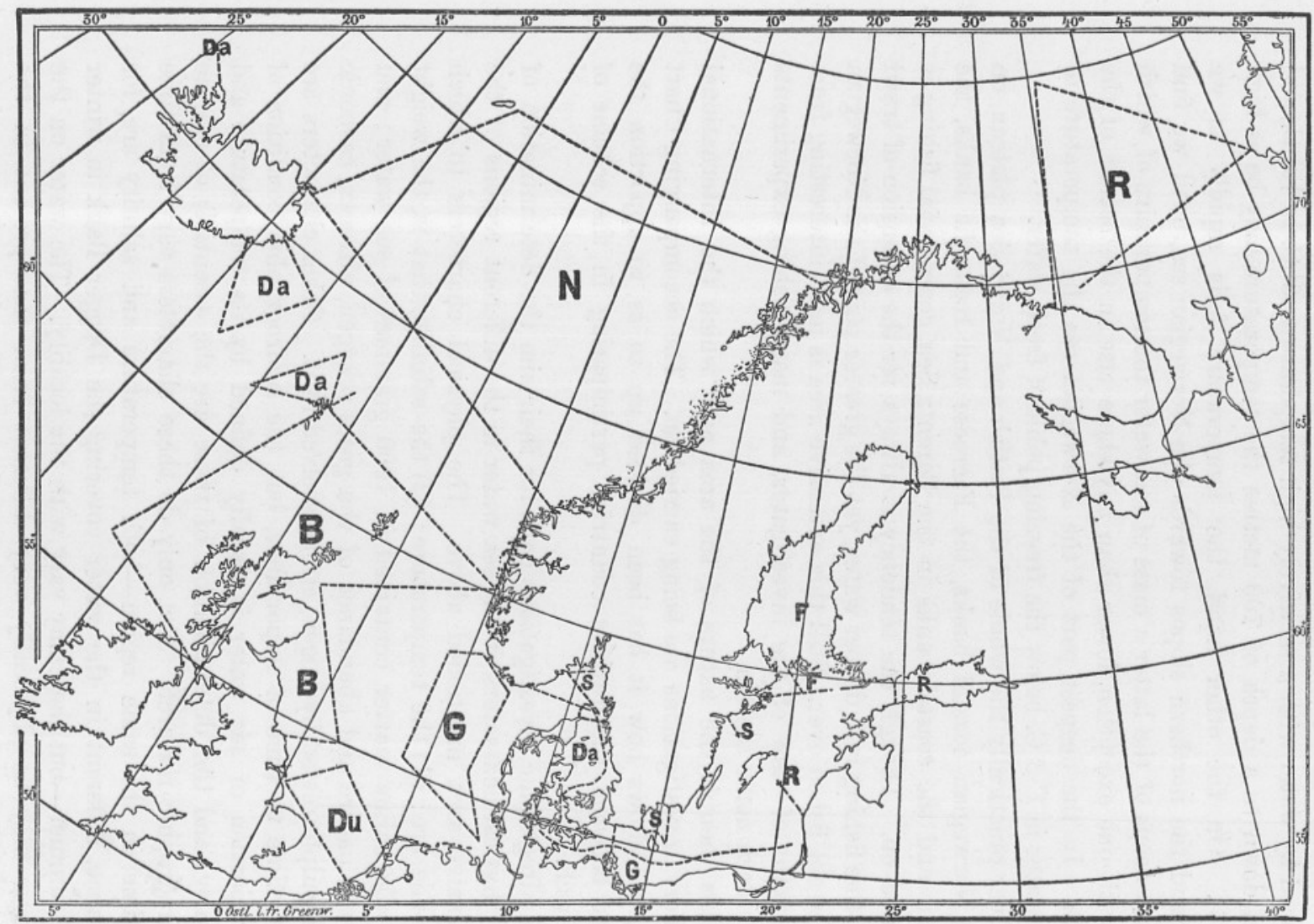

Fig. 1. Chart showing the Lines of Observation recommended by the Stockholm Conference, adopted with slight modifications by the Christiania Conference. 
A good deal of scientific work of this kind was carried on, both by the Scandinavian hydrographers and by the Scottish Fishery Board, prior to the beginning of the International Investigations. There was, for instance, a notable expedition in 1893, in the course of which results of some value were obtained; and, both in Norway and Sweden, frequent investigations, by vessels equipped for the purpose or by commercial vessels, have been made. I refer, of course, to hydrographic work in the North European area. It is well known that such research always formed a prominent part of the work of the great exploring voyages. But much of the research carried on in this part of North European waters is now known to be faulty; and the results obtained cannot be utilized for comparison with those now being procured by the International organization. Methods were faulty in the pastparticularly the methods of obtaining water samples and temperatures from deep-water levels or from the sea bottom. Even the determination of the salinity of the sample was not always carried out with accuracy. It was not until the creation of the International organization that co-ordination became possible. It was essential that the work should be carried on under the supervision of a central authority, and that large numbers of observations should simultaneously be made over a very extensive area. It was further essential for strict accuracy that water samples should be obtained and temperatures observed by instruments of identical pattern. When the International scheme was initiated in 1902 all these things became practicable. The region under investigation was divided into a number of sub-areas, one or more of which were allotted to each of the participating countries. In each of these sub-areas lines were marked out traversing significant portions of the sea area, and on each line were laid down a number of "stations." A station is a stopping-place for the exploring vessel at which observations are made. On reaching the station an ordinary sounding is made and a sample of water from the surface of the sea is taken, part of which is reserved for analysis. The temperature of the sea surface being determined, a series of hydrographic soundings is then made.

Not the least creditable achievement of the International Fisheries researches is the perfection of the water-bottle. In the latest form of this instrument, which was designed by Professors Pettersson and Nansen, we have an almost perfect means of collecting samples of water from the sea bottom or at any other depth, and at the same time determining the temperature of this water in situ. The water-bottle in principle consists of a central chamber, in which is fixed a delicate deep-sea thermometer. Round this central chamber are a number of concentric cylinders of ebonite and brass. The bottle is lowered in an open condition, and when the required depth has been attained it is 
closed by means of a "messenger," which slides down the line carrying the bottle. Both central and concentric chambers are then filled with the water present at the depth to which the instrument is lowered; the thermometer registers the temperature of this water in the central chamber, and this being surrounded by three or four concentric shells of water, heat is only very slowly conducted in either direction through these water walls. In hauling the water-bottle the temperature does not, therefore, appreciably rise. These soundings are made for a number of depths, for instance, $5,10,20,50,100$ metres, and the temperatures of these separate water strata are so obtained.

Each exploring vessel makes one such cruise at regular intervals, and the cruises over all the International area are made as nearly as possible at the same time. At least one cruise is made quarterly, and the months selected are February, May, August, and November. On the return of the vessel to her base, the water samples collected are sent ashore for analysis, and the salinity at least is determined. What is actually done is to estimate the percentage of chlorine (or rather total halogens) present by precipitating these substances, according to various methods, by nitrate of silver. The total solids in solution are then calculated from the values obtained in the analyses by means of hydrographic tables. The highest degree of accuracy is necessary, and this has only been made possible by means of check analyses made by the Central Laboratory, under the control of the International Council. The principal functions of this institution are the supply of the instruments of research, the preparation of "standard" sea water for checking the analyses made by the various national laboratories, and the preparation of the hydrographic tables.

The results obtained-salinities, temperatures, etc.-are then sent to the Bureau of the International Council to be published in the Bulletin des Résultats. The values are marked on charts of the areas under investigation, so that synoptical representations of the hydrographic condition of the sea are prepared. Such charts of temperatures and salinities, prepared for successive years or portions of a year, are pictorial representations of the circulation of the waters of the North Atlantic seas.

The immediate cause of these water movements in the North European area is the Gulf Stream circulation. It is now generally known, though one may still find it stated otherwise in the textbooks, that the actual Gulf Stream does not at any time reach the shores of the British Islands. Issuing from the Gulf of Mexico, this great current forms a closed eddy in the North Atlantic Ocean, and its waters circulate round a portion of that sea, characterized by the presence of floating seaweed and a peculiar fauna. This is the "Sargasso Sea." In 1889 the limits 
of the Gulf Stream eddy were investigated.* The water of 36 and 37 salinity touched the Azores in March of that year, but not the coasts of Africa or Europe. Between these coasts and the stream was water of less salinity than 36 . In November a great extension of the eddy had taken place, and in that month it had actually touched the coasts of Africa and Southern Europe. With this extension of heavy and relatively warm sub-tropical water had also occurred an extension of the area containing sub-tropical microscopic drifting organisms. In March of the following year the limits of the Gulf Stream eddy had again contracted.

The Gulf Stream circulation, though it never actually reaches our northern latitudes, thus undergoes a periodic expansion and contraction. Now analogous to these gigantic annual pulsations there occur hydrographic events in the seas of Northern Europe. A periodic flooding of the North Sea, the Skagerak, the Norwegian sea, and even the remote Barentz Sea, with water of Atlantic origin, occurs annually in such a manner as to render it an undoubted fact that the oceanic circulation in these regions is dependent on that of the Gulf Stream, and ultimately on the equatorial current. In some way or other a great stream or drift takes origin in the Gulf Stream eddy and invades our northern seas. This is the "European stream." It is sometimes said that it is the result of the propulsion of surface water by the prevailing south-westerly cyclonic storms which reach our latitudes. This may be so, but the cause of the Norwegian stream is more probably a complex thermo-dynamical one. Anyhow, there is a continual drift of relatively warm and dense water from the south-west towards Northern Europe. Just as the Gulf Stream eddy pulsates, so does this drift of water become augmented or contracted. And with these augmentations and contractions of the European stream are correlated changes in the barometric pressure and temperature of the atmosphere, and in the prevailing fisheries of the regions into which it penetrates.

The chart $†$ (Fig. 2 ) reproduced on page 444 illustrates the distribution of the European stream in August, 1896. This chart was constructed from observations made prior to the beginning of the International Investigations, and the results obtained since 1902 indicate that the distribution of the stream in 1896 was rather abnormal. A glance at the chart, however, will illustrate what may perhaps be regarded as the maximum flooding of the European seas by Atlantic water. The stream has invaded the Icelandic coastal regions, and has penetrated into the Denmark strait between Iceland and Greenland. Impinging on the

* Cleve, Ekman, and Pettersson, Variations annuelles de l'eau de surface de l'ocean atlantique.

†Petermann's Mittheilungen, 1900, Heft i. $u$. ii. ; see also Rappts. et Proc.-verb., vol. iii., 1905 , p. 4 . 
western coasts of the British Isles, the stream divides, part passing through the English Channel into the North Sea. Then flowing north, it is shown filling up both the Iceland-Faeroe and the Faeroe-Shetland channels. The International researches have shown that this distribution is quite unusual; as a very general rule the Atlantic stream passes between the Faeroes and Scotland only, and to a very slight

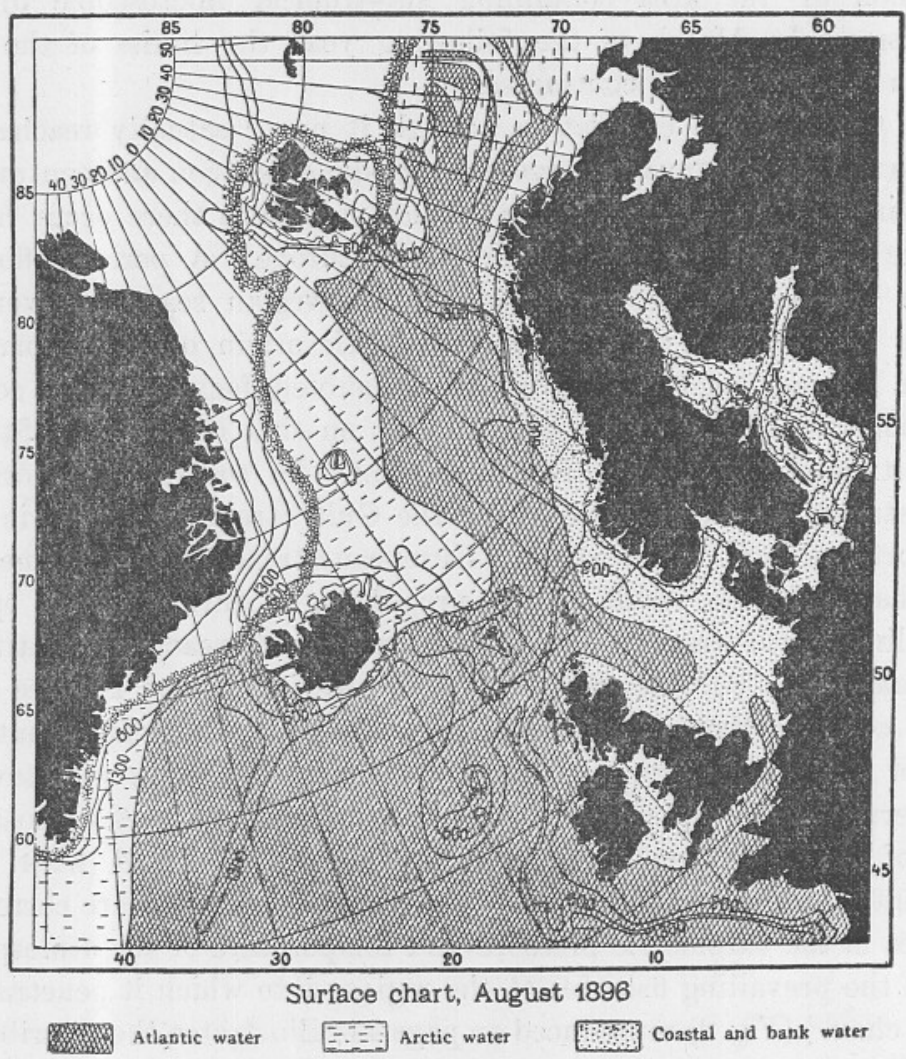

Fig. 2.

extent through the other channel. It should be noted that the whole of the oceanic basin from surface to bottom south of the IcelandScotland ridge is filled with Atlantic water. But the effect of the stream washing on the ridge is such that the flow of Atlantic water is interrupted, and north of the ridge this warm and dense water lies only on the surface. After passing over this ridge the stream, which is now the "Norwegian branch of the European stream," is deflected to the east, and we see that it rounds the north of Scotland and enters the North Sea. 
Great attention has been directed to the flow of the European stream on the Wyville-Thomson Ridge, and the investigations made since 1902 by the Scottish hydrographers in this region have shown that the conditions here are very complicated. Not only have we to consider the fluctuations of the Atlantic stream itself, but we have also to consider the influence exerted on the flow of the current by the North Polar stream. In the chart this is represented by the broken oblique lines. The Polar stream, which consists of cold and relatively light Arctic water flowing to the south, is broken into two sub-streams. One of these, the Greenlandic stream, is an ice-bearing one, and flows through the Denmark strait. The other, which does not usually carry ice, is the east Icelandic Polar stream, and flows south past the east coast of that island. This stream attains its maximum volume in spring, and it may then obstruct the flow of Atlantic water north of the Faeroe-Shetland channel and so cause this to enter the North Sea in increased volume. In the winter, when the flow of Arctic water southwards is at its minimum, the passage northwards of Atlantic water is facilitated. Not only does the varying intensity of the Polar stream affect the northerly passage of Atlantic water, but we have also to deal with an undercurrent of Arctic water which flows, beneath the Atlantic water in an opposite direction, and also with an outflowing stream of brackish water from the Baltic, which also exerts its influence on the intensity of the Norwegian stream. Altogether the hydrographic conditions in the Faeroe-Shetland channel are very complex, and it has been, and is still, a task of much difficulty to unravel the course of the currents in this locality.

After passing the Faeroes the Norwegian stream flows on to the north-east, covering a variable area of the surface of the Norwegian sea with water which is warmer and salter than that which lies beneath. Passing the meridian $25^{\circ} \mathrm{E}$. it then rounds North Cape and enters the Barentz Sea. The Russian hydrographers have investigated the physical conditions of this area with great success, ${ }^{*}$ and have shown that this North Cape current of Atlantic water and its ramifications possess boundaries as constant geographically as those of rivers. Annually the remote Barentz Sea is invaded by a heat wave, the result of the seasonal fluctuation of the Norwegian stream. The cold season or winter of this sea is in June. Beginning in that month is the inflow of Atlantic water, which attains its maximum intensity in November. In the interval between June and November the temperature of the bottom water in the Barentz Sea has been raised from $1^{\circ} \mathrm{C}$. to about $6^{\circ} \mathrm{C}$, and corresponding variations in the salinity of the water have

* Oceanographische Studien u. d. Barentz Meer. Petermann's Mittheilungen, 1904, p. 46. Also Rappts. et Proc.-verb., vol, iii., 1905, p. 3. 
been observed. Then in November the inflow of the genial Atlantic water ceases and the Barentz Sea is again invaded by the cold Arctic water of the Polar basin.

In the North Sea similar variations in the nature and origin of the water present have been observed. A good deal of attention was paid to this question even before the initiation of the International Investigations, but since 1902 our knowledge of these variations has been

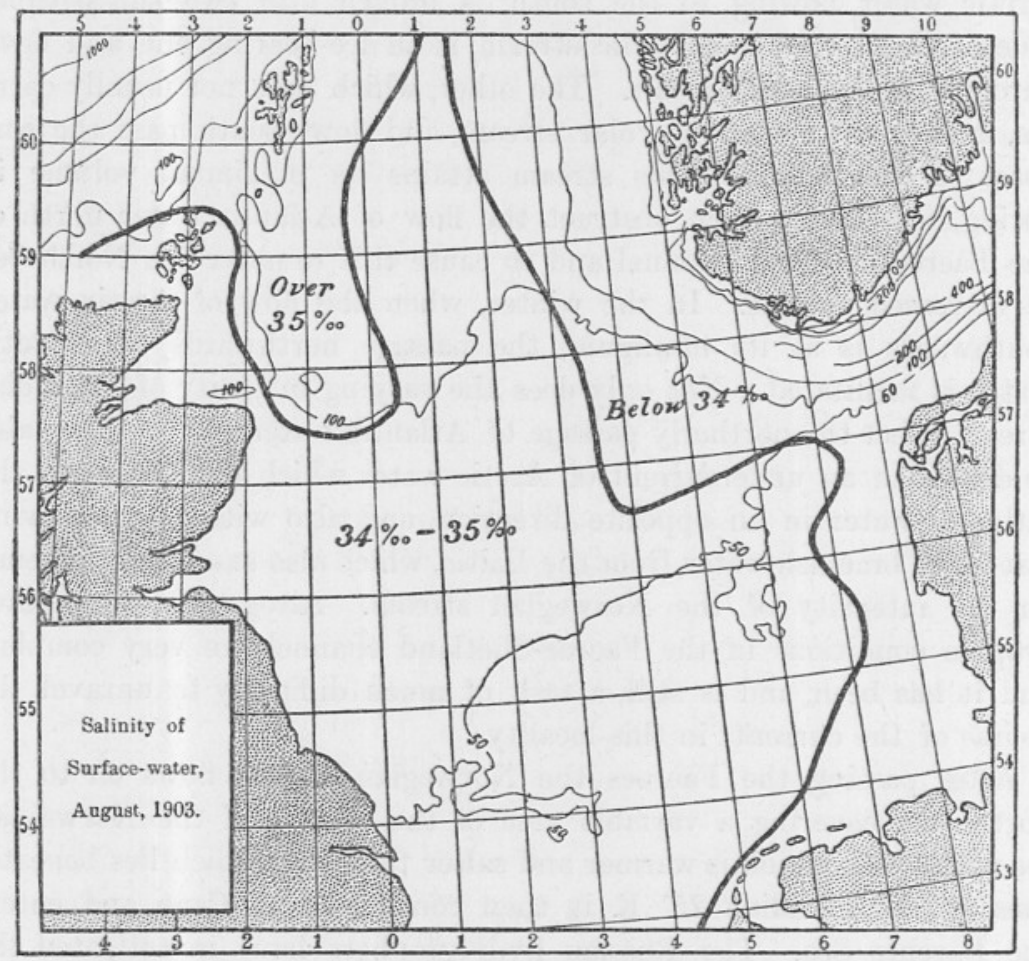

FIG. 3 .

considerably increased. The effect of the seasonal fluctuations in the volume of the Norwegian stream is well shown by the investigations of the Scottish, Danish, and Dutch sections of the organization, and will easily be understood by a glance at the charts,* which illustrate the hydrographic condition of the surface of the North Sea in 1903 and 1904. Fig. 3 represents the conditions in August, 1903, and it will be seen that by far the greater portion of the area is covered with water of 34 to 35 per 1000 salinity. This may be called North Sea water.

* A. J. Robertson, Fishery and Hydrographical Investigations in the North Sea and adjacent regions, p. 55, 1905 (cd. 2612). 
Then to the eastward there is a wide edging of water which is less salt, containing less than 34 parts of solid matter per 1000. This is Bank water, and results from the fusion of North Sea water with the fresh water from continental rivers and from the outflowing Baltic stream. In this month Atlantic water is seen to be present in the north-west part of the North Sea; that is, the Norwegian stream has begun to flow round the north of Scotland, and covers the deeper part of the North Sea, north of the Dogger Bank.

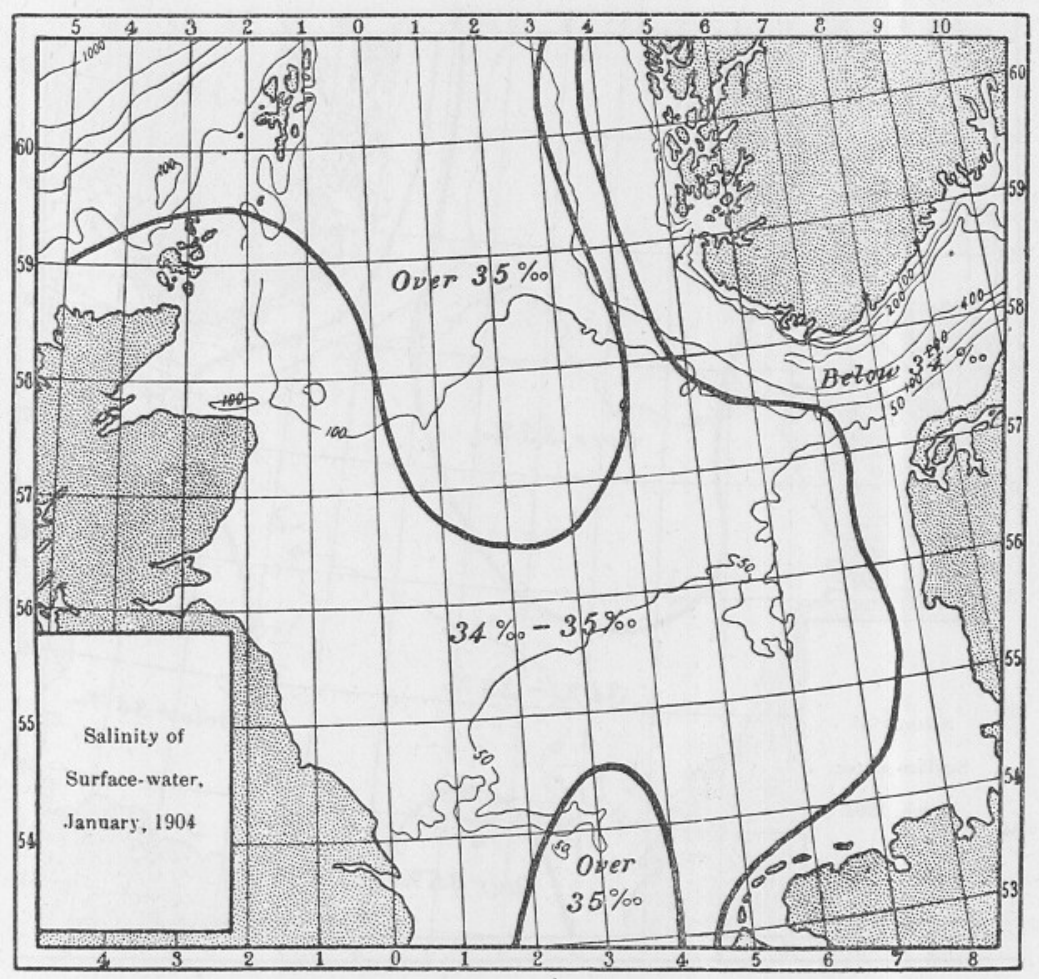

Fig. 4.

So far there is no indication of the entrance of Atlantic water into the North Sea area from the southern entrance. This, however, is represented in Fig. 4, which shows the conditions obtaining in January, 1904. Here we see that the northerly tongue of Atlantic water proceeding from the Faeroe-Shetland channel has become much larger and now covers quite an extensive area of the sea. Towards the south Atlantic water is also entering through the Straits of Dover, and these north and south influxes of salt water are apparently approximating to each other. In the next chart (Fig. 5), which represents the conditions 


\section{SOME RESULTS OF THE INTERNATIONAL FISHERY INVESTIGATIONS.}

in March, 1904, a further development of the Atlantic flooding has taken place. Both the northern and southern tongues have become largely augmented, and Atlantic water now covers quite a considerable fraction of the North Sea area. The influx of water from the European stream into the North Sea therefore begins in August, gathers force during the winter, and attains a maximum in early spring. From thence onwards the flooding diminishes.

The work of the Swedish hydrographers, carried out under the

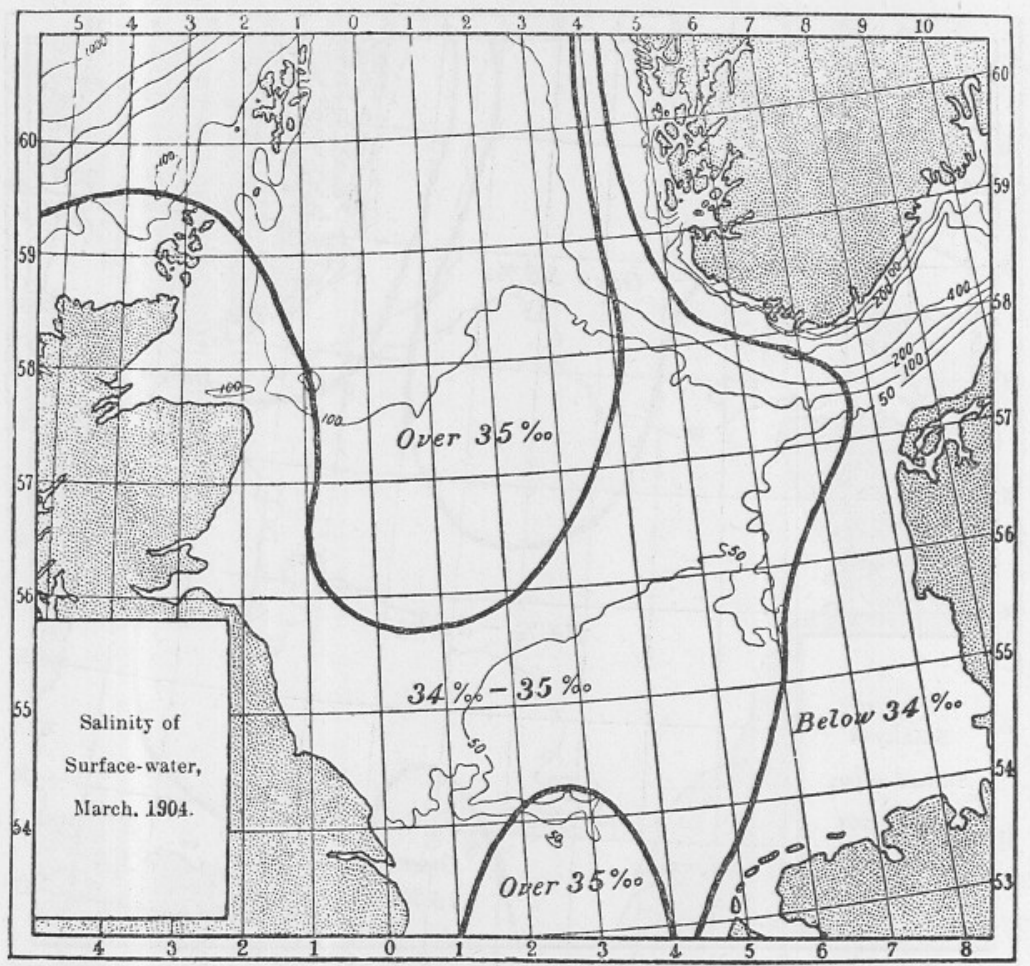

FIG. 5 .

International organization, in the Skagerak, and that of the Danes in the Cattegat and the Belts, show that the same ebb and flow of Atlantic water can be felt in those seas. "During the autumn," says Pettersson,* "a heat wave from the Skagerak penetrates into the Baltic." From August until November Atlantic water accumulates in the deep layers of the Skagerak. In August this is overlain by surface water of low salinity and a relatively high temperature. When in November this accumulation of salt water has reached its maximum, both of volume

* Rappts. et Proc.-verb., vol. iii., 1906, p. 8. 
and temperature, it lies beneath surface water which is now much colder than that at the bottom. The effect of this flooding of the deeper regions of the Skagerak with warm dense water is that an undercurrent of relatively warm Bank water is set up, and this passes through the Cattegat and the Belt seas into the Baltic proper, where it displaces the colder water which had accumulated during the previous winter. In most years this undercurrent of warm Bank water may pass as far into the Baltic as east of Bornholm.

Finally, the hydrographic observations made in the English Channel by the Marine Biological Association* show that the same periodic flooding by warm and dense Atlantic water takes place in this area. In the Channel, on account of the rapid and complicated tidal streams and the contracted sea area, the conditions are more complex and difficult of investigation. We have here to deal with two contributory sources of water: (1) a current of relatively low salinity which flows southwards from the Irish Sea; and (2) Atlantic water which flows northwards from the Bay of Biscay. The conditions are still further complicated by the presence of coastal water. A general drift of water up Channel has been observed, and successive areas of low and high salinity water may pass to the east. During the summer and early winter of 1903 the low salinity water of the Irish Sea predominated, but in the winter the Channel was largely filled with Atlantic water flowing past Ushant in a north-easterly direction.

The main results which already appear from a study of the hydrographic work of the International Fisheries research organization are these: (1) the flooding of the seas of Northern Europe by a stream of comparatively warm and heavy Atlantic water which takes origin in the Gulf Stream circulation; and (2) the periodicity of this Atlantic drift. Once a year the area covered by the gigantic Gulf Stream swirl expands and contracts, and once a year, but a little later, the continual northerly flow from the Atlantic to Britain and Northern Europe also is augmented and diminished. It is in the remoter parts of the area invaded by the European stream that the pulsations of the latter can most easily be felt. In the English Channel, the North Sea, the Cattegat and Baltic, the shores of Iceland, and the Barentz Sea, the annual heat wave set up by the replacement of the colder and fresher waters of those seas by the warmer and salter waters of the Atlantic has now been observed and studied.

The efforts of the International organization are now being concentrated, so far as hydrographic research goes, on the study of the

* Matthews, Report (No. 2, Southern Area) Fishery and Hydrographic Investigations in the North Sea and adjacent regions, 1905, p. 289 (cd. 2670). 
varying periodicity of the Atlantic flood and ebb. We have seen that the Gulf Stream circulation is itself periodic in that its intensity is greatest in November and least in March. But that the period of greatest intensity varies slightly from year to year is now tolerably certain, though this problem has by no means received the attention it deserves. So also with the appearance of the Atlantic stream in the ultimate seas of Northern Europe; on the whole an annual periodicity has been observed. Year after year the Atlantic flooding occurs at much the same time: the temperature of the water rises, and the salinity increases in such a manner as to eliminate the possibility that these changes are due to local climatic influences, and to render it certain now that they are due to a great oceanic water circulation affecting at nearly the same times areas far apart from each other. But there are perturbations.

The study of these perturbations belongs to the future, but already there are evidences of regular disturbances in the periodic ebb and flow of the Atlantic current. In thirty-nine years' records of the temperature of the atmosphere in the central part of Sweden, and that of the sea off the coast of Norway during the cold seasons, a two-yearly period is clearly apparent. Both in the air and in the sea maximum and minimum temperatures occur with great regularity every two years. This is the phenomenon known to meteorologists as that of the "odd and even years." As a rule, the "even" years of the last thirty have had more temperate winters than the "odd" ones. That this observation applies equally to the temperature of the sea indicates that the cause of the biennial periodicity of the air temperature is a hydrographic one. In addition to this smaller perturbation we can obtain elusive glimpses of other larger disturbances-secular variations due probably to cosmical causes -in the regularity of the yearly flow of the European stream. Biological phenomena afford indications of these larger irregularities. Since the year 859 the appearance of winter herrings in the Skagerak has been recorded, and it is observed* that the fishery has returned with intervals of, on the whole, 111 years.

Both climatic changes and changes in the abundance of the fisheries are thus connected with hydrographic phenomena. One of the most valuable means of research to the meteorologists of the future will be hydrographic investigation, and for the rational study of the fisheries this line of research will prove no less useful. Already it is beyond doubt that hydrographical and biological phenomena are closely related, and the work of the next few years is likely to furnish further instances of this connexion.

* Pettersson, Rappts. et Procès-verb., vol. iii., 1905, pp. 13-19. 


\section{Biological Investigations.}

The results of the strictly biological investigations carried out under the auspices of the International organization are less novel than those hydrographical results to which we have already referred. Sea fisheries research, both in Great Britain and on the continent of Europe, has in the past been largely concentrated on the elucidation of the life histories of fishes and other edible marine animals. Beginning in 1865 with G. O. Sars' classical investigation of the spawning of the cod on the fishing grounds off the Lofoten Islands, this work was developed at first principally by McIntosh and the St. Andrews school of zoologists; and when fisheries investigation received official sanction and support in this country, it was very actively pursued in Scotland by the naturalists of the Fishery Board, and afterwards in England by the Marine Biological Association. When in 1902 the International Investigations were commenced a very considerable store of knowledge of this branch of fishery science already existed," and subsequent work in the countries participating in these researches has been devoted to filling up lacunæ in those results and in synthesizing the investigations by the adoption of methods of research on a larger scale than was previously possible and by new forms of apparatus.

It is unnecessary to recapitulate here the main features of our knowledge of the life histories of northern fishes. $\dagger$ The reader will remember that the great majority of North European food fishes reproduce during a limited period of the year-three months or so, some time between the end of the year and midsummer-the precise dates and durations of these breeding seasons depending both on the species of fish and on the localities under consideration. The exact incidence of the breeding season is not constant from year to year, but varies, and one of the main results of the International hydrographic investigations has been to associate the onset and duration of the breeding season with the hydrographic condition of the portion of the sea considered. Generally speaking, the majority of British food fishes spawn during the months March to June.

The eggs produced by these fishes are now fairly well known, though, of course, our knowledge on this point is not quite exhaustive. Most fish eggs belong to the pelagic type-that is, they are lighter than sea water of normal constitution and float at or near the surface. But the

* This has been admirably summarized by P. P. C. Hoek in No. 3 of the Publications de Circonstance, August, 1903.

+ See also Cunningham's Marketable Marine Fishes, 1896; Holt's Account of the Grimsby Trawl Fishery (published by the Marine Biological Association); and McIntosh and Masterman's Life Histories of the British Marine Food Fishes, 1897. 
eggs of the herring are of the demersal type, and when spawned by the parent sink to the sea bottom, where they adhere to whatever objects with which they come into contact. Upon this difference depend differences in the further distribution and development of the two classes of eggs. The pelagic eggs are drifted anywhere in the upper layers of the sea, according to the force and direction of the surface drift of the water, whether the latter be due to tidal streams, to the influence of prevailing or exceptional winds, or to the larger movements of sea water which we have been considering as hydrographic events. These passive migrations carry pelagic fish eggs from the regions inhabited by the parent fishes at the spawning seasons into others where the conditions influencing their further development may be very different, and it is in respect of this influence upon fish eggs and their development that hydrographic investigation may be expected in the near future to be of much service to the fishery investigators. Demersal eggs, on the other hand, being deposited in the regions chosen by the parent fishes, and at the bottom of the sea, where hydrographic changes are less violent, are assured of more constant conditions for their development. It is probably because of these facts that the great summer herring fishery of the East British coast waters is so constant in its appearance and duration; and to them is due also the well-marked variations which herring exhibit in different parts of this extensive area. "Races" of herring, if such really exist, are probably due to the fact that the various herring shoals frequent the same sea areas from year to year, and that their eggs develop in the regions where deposited.

The development of the eggs of the various species of food fishes, and the subsequent life history of the larvæ, which hatch out after a fortnight or so of incubation, have been worked out in considerable detail in the past. The tracing out of the development of the embryo and larva was a task of no great difficulty, and could easily be carried out at the marine laboratories, even at the small ones, with no great wealth of apparatus. All that was necessary was to procure the fertilized eggs of the species to be investigated. This was usually done by "stripping" mature fishes, that is, by expressing the ripe eggs and spermatozoa from the reproductive organs and then keeping the eggs and larvæ in running sea water in small tanks and patiently studying the changes taking place during the developmental period. So we find in the literature, English, Danish, Norwegian, and German, detailed descriptions of the life history of most edible fishes during the first few weeks of life. Comparatively little has been added to this literature by the International investigations of the last four or five years. It is with regard to the further life history of the fish that most recent 
work has been concerned. After the hatching of the larva from the egg there is a period of growth of which little is known. Some weeks after hatching the "metamorphosis" of the larva is effected. The little fish now takes on the shape of the adult, and gradually assumes the habits and food of the latter. During the period of juvenescence the life history must be studied in the sea itself, and the growth and migrations observed in specimens taken in the most diverse localities by means of special fishing apparatus. Neither the commercial nets of the fishing fleet nor the older dredges or "townets" of the naturalists afford any assistance in these investigations. Altogether new fishing apparatus have had to be devised, and it has been necessary to carry out researches far out at sea, in regions where fishery work was, under the older methods, usually quite impracticable.

Such investigations have been carried out by the naturalists of the Danish, Norwegian, and German sections of the International organization by means of specially designed fishing apparatus. The "Scherbrutnetz" was designed by Ehrenbaum and Strodtmann,* of the Heligoland Biological Station, for the capture of larval fishes. This instrument is a very large townet with a square opening. The special feature of the apparatus is the "sheering-board," a large board attached to the lower edge of the mouth of the net, and inclinable at any angle; by means of this contrivance, which acts in the same way as the otter-board of the commercial otter-trawl, the net can be towed at any desired depth. The "young-fish trawl" of Petersen $\dagger$ is a still more effective instrument, which is constructed on the principle of the large otter-trawl, and is able to fish at the sea bottom or at any depth from the surface. The net, being composed of material with a very fine mesh, is adapted to catch very small fishes.

The invention and use of these two forms of fishing apparatus are so important for the investigation of the pelagic or young free-swimming stages of edible fishes that one might almost say that their application begins a new era in fisheries research. The older surface townet captured pelagic larval fishes only in very small numbers, and it was always difficult to use this instrument with much success at the bottom or at intermediate sea levels. We know now that results obtained by the use of ordinary townets in the past were totally misleading so far as affording reliable information as to the distribution and abundance of young stages of sea fishes. Joh. Schmidt, ${ }_{+}^{+}$for instance, gives a record of a haul of the young-fish trawl taken from the Danish investigation steamer Thor off the coast of Iceland, at a depth of 79 metres (about 40 fathoms),

* Wissensch. Meeresuntersuch., Bd. i., Abteilumgen Helgoland.

† Slcrifter af Kommission for Havunersögelsen, Nr. 1, 1904.

‡ Meddelelser Komm. Havundersögelser, Ser. Fiskeri, Bd. i. No. 4, 1905.

NEW SERIES, VOL, vII. No. 5 . 
which in thirty minutes captured about seven thousand specimens of young stages of pelagic and bottom-living fishes, belonging to twentytwo different species. We are assured that this haul is "far from being the richest in individuals made by the Thor." No method of investigation practised in the past afforded this wealth of material. Not only are naturalists nowadays in possession of a means of research enabling them to obtain rich stores of material for the study of the developmental histories of fishes, but they are also able to form reliable estimates of the wealth of fish life in the sea at early stages, and to trace with some probability the migrations of the larvæ and young fishes. The first results of the study of developmental histories of fishes made by the help of those fishing apparatus are published in the Danish Meddelelser. In the paper already referred to Joh. Schmidt gives the first instalment of a study of the free-swimming post-larval stages of the fishes of the North Atlantic belonging to the genus Gadus. This monograph includes the cod, coal-fish, whiting, haddock, pollock, and other less known gadoid fishes, and in it the author attempts, for the first time, a systematic description of the characters of the post-larval fishes at different stages. It is well known that the recognition of young fishes in their very early life is a task of much difficulty, and some considerable degree of uncertainty has always attended the identification of nearly allied fishes, such as the cod, haddock, and whiting, in the stages following the metamorphosis, and before the little fish assumes the wellknown characters of the adult. By making a systematic study of the colour markings of the young fishes, which, it should be remembered, are quite different from those of the adult, Schmidt has been able to classify the post-larval fishes of the cod family in much the same way as the adults have been treated. The identification of these young fishes has therefore been greatly facilitated for future observers. Making use of material collected also by the young-fish trawl of the Thor, Schmidt* has also given us by far the most complete accounts of the life histories of the halibut and torsk (or tusk) in the literature. The description of the series of stages of the halibut is particularly welcome, since the development of this fish is more obscure than that of any other of the flat-fishes. Again, the early stages of the long rough dab, a fish relatively common off the east coast of Britain, have been studied by Petersen, and our knowledge materially advanced. $\dagger$

But by far the most important contribution to our knowledge of the early life histories of edible fishes is the discovery by Schmidt and Petersen $\ddagger$ of the spawning place of the European fresh-water eel. The

\footnotetext{
* Meddelelser Komm. Havundersög., Bd. i. Fiskeri, Nrs. 3 and 8, 1904-5. † Meddelelser Komm. Havundersög., Fiskeri, Bd. i. Nr, 1, 1904.

¥ Ibid., Fiskeri, Bd. i, Nrs. 5, 6, 1905 .
} 
early development of both the fresh-water eel and the conger-eel has always been very imperfectly known. It is now well known that the peculiar flat, ribbon-like, and transparent fishes called "Leptocephali" are the young stages of the fresh-water eels. Leptocephali are very rarely found on the coasts of Britain or Northern Europe; the few finds that have been made are all recorded in the literature. Nevertheless, every year in the spring and summer enormous numbers of small flat eels of varying degrees of transparency are found all along British and continental coasts. These young eels, or "elvers," are the transformed Leptocephali returning from the sea into the rivers. When the eel approaches maturity it descends the rivers to the sea, assuming as it does so a peculiar coloration, or "bridal dress." In the sea it becomes mature, spawns, and the larva which develops becomes, at an unknown time after the hatching of the egg, the Leptocephalus. Before the latter larva reaches the coasts it undergoes metamorphosis and becomes the "elver." So much has long been known, but the further questions - the character of the eggs, their development and hatching, the development of the larvæ, the place and time of spawning, and the duration of the embryonic and larval periods - all have been profound mysteries. The Leptocephalus is, in fact, the first stage in the development of the eel; that is well known. Of the earlier stages we know next to nothing. What we do know is due to the investigations of Grassi and Raffaele in the Mediterranean, and may be summed up by saying that the eel spawns in relatively deep and warm water some distance from the land.

But this lack of knowledge of the spawning habits and development of the eels (both fresh-water and marine forms) is due, without doubt, to our hitherto very imperfect methods of investigation. Given the right form of fishing apparatus and some considerable range in the area over which this is used, and there is no doubt that all stages of the eel, from the developing egg to the Leptocephalus, should be found in abundance. This occurred to Petersen in connexion with the use of the small-fish trawl. "The Leptocephali," he says, "will surely be found, I thought, if we seek them in the right time, place, and manner." During a trip to the Faeroe Isles and Iceland in 1904 the Thor had to pass through warm and deep Atlantic water, and on fishing at a station* south-west from the Faeroe Isles on May 22nd, 1904, a single Leptocephalus was taken in the young-fish trawl. In 1905 Schmidt again succeeded in finding "great quantities of Leptocephalus brevirostris in the depths of the Atlantic." $\dagger$ Considered both as a contribution to the natural history of the eel, and as a fact which is likely

* $61^{\circ} 21^{\prime}$ N.; $19^{\circ} 59^{\prime}$ W.

† Meddelelser Komm. Havundersög., Fiskeri, Bd. i. Nr. 5, 1905, p. 5. 
to be of advantage for the direction of the continental eel fisheries, the importance of this discovery can hardly be over-estimated. We now know that the lack of success which has attended the innumerable attempts to find Leptocephali in shallow in-shore waters, and even in restricted sea areas, like the Baltic, the Cattegat, the North Sea, or the Irish Sea, is due to the fact that these larvæ do not frequent those waters, and that the rare captures which are recorded in the literature are those of individuals the development of which has for some reason or other been greatly retarded. There is no longer any doubt that the eel does not spawn in fresh water, but must emigrate to the open sea before it can reproduce. If it is hindered from making this migration it will die without spawning. Further, the fish spawns in deep and relatively warm water in the open Atlantic, north-west and west from Scotland. To reach this region the parents must pass through the Baltic if they have been living in some of the great continental rivers, and most of the North European fresh-water eels must make a very lengthy spawning migration, in the course of which they traverse the North Sea, the Irish Channel, or the English Channel before they attain the conditions necessary for the maturation of the reproductive organs. It will readily be seen that a complete knowledge of these migration paths and seasons, such as no doubt will soon be obtained by following up these observations, must prove of great importance, not only for the development of more rational methods of fishing, but also for the elaboration of useful legislation regulating the fishery.

Following up Schmidt's discovery of Leptocephali in the Atlantic, Johansen has materially added to our knowledge of the life history of the eel in its "elver" stages. It is well known that the elvers, which are the metamorphosed Leptocephali, ascend the rivers from the sea in immense numbers in the spring of the year. But our knowledge of the elvers in the sea itself has hitherto been very scanty. Again the explanation is that they were not looked for in the proper time and manner. The young metamorphosed eels are pelagic at night, that is, they swim at some distance from the bottom in intermediate depths. During the day, on the other hand, they live on the sea bottom. In the sea the elvers are almost colourless, though they differ greatly from the leptocephaline stages. A smoky-brown pigment first appears on the tip of the tail and on the head. As the transformation from the Leptocephalus to the elver stages proceeds this pigment gradually invades the rest of the body. At the same time the peculiar ribbonlike form of the Leptocephalus is lost; the little fish becomes thicker from side to side and less deep from back to belly. Curiously enough, too, it becomes actually shorter from head to tail. The almost colour-

* Medd. Komm. Havundersög., Fiskeri, Bd. i. Nr. 6, 1905. 
less elvers which have appeared in the sea off the coasts in the early spring become gradually transformed, and by the middle of summer they have taken on the form and colour of the adult eel, and have begun to grow again after the first decrease in length which accompanies the larval transformation.

This is hardly the time to say anything about the researches on the distribution and abundance of the pelagic stages of very young fry of the marine food fishes. Many observations have been made, and are actively being prosecuted, by the Danish and Norwegian naturalists on the staff of the International organization, which have for their object a complete knowledge of what becomes of the multitude of fry which are hatched out in our seas during the spawning periods. An essential part of such investigations is, however, the comparison from year to year of the records obtained, and we must wait for some time before conclusions of value have been made. Leaving aside the case of the herring, we may say that the pelagic fry of almost any marine food fish do not remain in the place where they are born. Nearly all fishes shed their eggs into the sea, and these are then drifted about from place to place at the mercy of the winds, tides, and currents. Even when the young fishes or larvæ hatch out from the eggs they are still among the feeblest creatures which exist in the sea, and with little or no powers of locomotion of their own, they are carried about over extensive sea areas. What becomes of them during these pelagic stages? The larvæ are not always present in those parts of the sea where the parents are numerous and vice versa.* Petersen, for instance, notes as remarkable that the young stages of the witch and lemon sole are abundant in the open sea off the coasts of Denmark, but "do not at all occur in the veritable Danish waters" inside the Skagen, that is, in the restricted seas of the Danish islands. Nevertheless, both of the adult fishes are present in these narrow seas in considerable numbers, and the witch is the object of a very considerable fishery in the Cattegat. Again, the same author $\dagger$ notices that there may be great differences between the larvæ of fishes taken in the open sea and larvæ of the same forms taken in in-shore waters. These differences apply to the size of the fry and to their coloration. Do these differences represent the variations between identical fish species taken in different sea areas? It has long been known that such "races" do exist. Henicke, for instance, has shown that the herring captured off different parts of the British and continental coasts present such differences as, in his opinion, are sufficient to justify the view that distinct races of herring are met with in different areas. Cunningham and others have concluded that different races or varieties of plaice exist

* Medd. Komm. Havundersög., Fiskeri, Bd. i. Nr. 1, p. 12, $1904 . \quad+I b i d$. 
in the North Sea and adjacent waters, from the notable differences in the size at which spawning first occurs in the fish taken from these fishing grounds. Garstang has made observations of varieties among mackerel, and Dannevig and others have also shown that distinct races of cod exist. Are these variable characters of the same species of fishes inhabiting different seas transmitted to the larvæ, and can they be recognized in these stages? This is only one of the questions which a far-reaching investigation of the distribution of the fry of fishes may be expected to solve in the near future.

\section{The life history of the Plaice.}

When the International Fishery Investigations were begun, particular attention was directed to the detailed study of a few food fishes-the plaice, cod, and herring. All these are of great economic importance: the plaice to the North Sea Fisheries of England, Denmark, and Germany; the cod to the Norwegians; and the herring to the Scottish. We may note at the outset that the problems of the distribution and migrations of the herring are intimately connected with those of the hydrography of the sea, and in the correlation of the latter researches with the statistics of the herring fisheries, the old problem of herring migration is likely to receive solution. "We are much inclined to believe that the great summer herring fishery comes and goes with this annual ebb and flow [that of the Atlantic stream in the North Sea], and much of our recent hydrographic work, since the date of that with which the present volume deals, has been directed to the study of this important subject."*

The problem of the plaice fishery, that is, the investigation of the life history of that fish with reference to the utility of legislative restrictions on the fisheries, has, however, been approached in quite a different way. The question of extreme interest to the English and continental plaice fishermen is whether or not a size limit would be of advantage to the industry. It has been proposed over and over again in this country to render it illegal by statute to land or sell a plaice which is below a certain size. With respect to the most suitable size limit very different opinions have been expressed. In official quarters, a minimum size of 8 inches of length has been favoured. Fishery investigators and some of those engaged in the fish trades have advocated higher size limits than 8 inches, and the merits of these various proposals have been very frequently discussed. Both scientific and economic questions are to be considered in any attempt which may

\footnotetext{
* D'Arey W. Thompson, Fishery and Hydrographical Investigations in the North Sea, etc., (cd. 2612), 1905, p. v.
} 
be made to elaborate legislation of this nature. Into the latter questions we cannot enter here, although it is evident that they are at least of equal importance to the scientific issues involved. But, at any rate, no one would recommend general discussion of the question apart from far-reaching and patient investigation of the natural history of the plaice in the sea at every stage of its life. In the investigation of the latter question, so far as it has been carried out, three main lines have been followed by those engaged in the International Fishery Investigations: (1) the distribution of the plaice on the various fishing grounds, with respect to the size and age of the fish present from month to month throughout the year; (2) the migrations of the fishes; and (3) the food of the plaice. Other lines of investigation have been followed, but in the main attention has been focussed on those indicated above. The distribution has been studied by means of fishing experiments, that is, numerous hauls with trawl and other nets made by the exploring steamers on the fishing grounds frequented by the commercial vessels, and statistically by means of a study of the results of the fishery by the fishing fleets themselves and by the examination of samples of fish caught by the trawlers and examined in detail afterwards. The fishery experiments have been made by "the various scientific vessels and naturalists of the national staffs, while the statistical work has been mainly carried out by the Bureau of the International Council and by the English Board of Agriculture and Fisheries.

Now the method of fishing experiments is, of course, of limited application, and conclusions derived from such results must be cautiously made. Like all scientific methods which depend on the examination of "samples," it is open to the objection that the sample may not really represent the general conditions. Such objections, for instance, would apply to thermometric or barometric charts representing the meteorological conditions of an extensive land and sea area at a given time. That is, the readings of the instruments, while true for the immediate area, might differ notably from those which would be obtained in an adjacent area where no readings had been made. The results obtained by fishing with a trawl net on twelve days in the year could not be compared, with any degree of certainty, with the results obtained by fishing with the same trawl on the twelve corresponding days of the following year in the same place. That is to say, so many accidental circumstances might influence the nature and amount of the catches made by the net that it would be risky to conclude that fish were more or less numerous at the given place in one year than in the other. But though such limitations must be imposed on the usefulness of fishery experiments, it is nevertheless the case that these are 
essential if we wish to understand the conditions of the sea fisheries. If we wish to know, for instance, whether small plaice are more abundant near the shore than in the offing, or whether they are more abundant in shallow than in deep water, or whether the plaice near the shore are larger or smaller than those off-shore, or what is the predominant kind of fish present from time to time on any part of the sea bottom; in all these, and in many other cases, it is only by making experiments with nets of different forms that we can obtain the desired information.

Such fishery experiments, made chiefly by means of the large commercial otter-trawl net, have been carried out by both the British and continental exploring vessels. It would be unprofitable at the present time to attempt to make exhaustive analyses of the results obtained. These are still incomplete-indeed, the results of the Scottish experiments are not yet published. It is when the results of the five years' experiments are collected that they can most usefully be discussed. But while this is the case, some results of interest are already apparent. The English fishery experiments show that small plaice are much more abundant in the shallow waters near the land than in the deeper waters off-shore. Plaice of less than 8 inches in total length were, as a rule, restricted to a strip of sea lying between the land and the 10 -fathom line. There they were relatively very abundant. On the shallow grounds off the coasts of Holland they were much more abundant than in corresponding depths of sea near the English coasts. On the "Eastern Grounds," that is, the shallow-water area off the islands of the Zuider-Zee, off Heligoland and the coast of Denmark, some distance from the land, the English steamer Huxley took average catches of from 180 to 2500 plaice of this size per hour of trawling.* On the fishing grounds of the same depths off the English coasts the Huxley never took more than 65 plaice per hour. Again, medium-sized plaice 10-12 inches long "were altogether absent on many of the English in-shore grounds"; but on the fishing grounds well off the land, in fact, over the greater part of the southern part of the North Sea, south of latitude $53^{\circ} 30^{\prime}$, in what may be called the Flemish Bight, these plaice formed an extensive portion of the catch. A legal size limit, if this should be adopted on an international scale, could not be greater than 12 inches if trawling for plaice were to continue on these grounds. Up to 12 inches in length the plaice is very generally an immature fish, that is, it has not yet produced spawn. The predominant plaice population of the southern part of the North Sea is therefore an immature one.

Mature plaice in the North Sea are very generally fishes of over

* Garstang, Fishery and Hydrographical Investigations, etc. (cd. 2670), 1905, p. 102. 
14 inches in total length. This is the average size, for the male fish when they first become sexually mature are smaller (one inch or more) than the females. Such fish spawn in the spring. It was formerly believed that during the spawning season plaice became crowded together on certain "spawning grounds." The trawling experiments of the Huxley lent little support to this belief, though there are certain indications that spawning migrations do occur. Such mature fish are not distributed everywhere over the fishing grounds. The Huxley found that they did not occur, or only very exceptionally, in the shallow waters within the 10 -fathom line. On the other hand, they were relatively abundant on the Dogger Bank, and here and there in the deeper parts of the North Sea well off the shore.

All fishery experiments made by the International naturalists agree in this respect, that on the eastern side of the North Sea, off the coasts of Holland and Denmark, in what has been called the Heligoland Bight, we have a predominant small plaice population. There is further agreement as to a general law of the distribution of this fish: that the deeper the water the larger the fish. This, of course, only applies to fishing grounds where the water is less than 50 fathoms in depth. It is safe to say that plaice are absent altogether, or at least very scarce, on sea bottoms of this depth. Indeed, outside the 20 -fathom line the fish is very scarce. It is most abundant near the shore, and becomes less abundant as the water gets deeper. The general law that the plaice increases in size as the water becomes deeper is nowhere stated so clearly as by Redeke.* This naturalist has analysed the results of the fishing experiments of the Dutch exploring steamer Wodan, made off the coast of Holland from the Hook to the Zuider-Zee. The distribution of the plaice of different sizes so constantly depends on the depth that Redeke has drawn lines on the chart which he terms "isomegalins." Each isomegalin is a line drawn approximately parallel to the coast. The isomegalin I bounds a narrow strip of sea in which only plaice of one to two years in age, and less than 10 centimetres (4 inches) in length, are to be found. Outside this, and parallel to it, is the isomegalin II, between which and the line I are only plaice of over two and less than three years of age, and from 10 to 15 centimetres (4 to six inches) in length. Outside isomegalin II is the line III, which again forms the outer limit of plaice of from three to four years of age and from 6 to 8 inches in length. The general law of distribution is stated by Redeke in these words: "The distribution of the plaice thus appears to be a function of its size, and is so uniform that one can almost say the plaice are so many centimetres long when the depth in which they are taken is so many metres."

* Rappts. et Proc.-verb, vol. iii., 1905. Distribution of the plaice on the Dutch coast. 
Such a "law," however it may apply to the conditions off the coast of Holland, is much too definite to apply to other localities. It is altogether incorrect when applied to some areas off the coasts of Britain. It is too often forgotten that all these statements of distribution are made with respect to areas where a long-continued fishery for plaice has been carried on, and where the influence of man as fisherman is continually exerted in reducing the numbers of large plaice. Large fish are more easy to catch, and must necessarily be fewer than smaller fishes; again, the fishery is, roughly speaking, most intense near the land, and decreases in intensity as we proceed further out to sea. This influence of fishing must operate in bringing about, to some extent at least, the distribution of plaice with size varying according to the depth of the sea. It is far otherwise in the few regions which are natural "plaice grounds," and where the law prohibits trawling. There, instead of a distribution such as is indicated above, we may find that plaice of all sizes and ages are living together on the same restricted portion of sea bottom.

The determination of the age of a plaice has been arrived at by means of two methods. One is that of Petersen, and depends on the analysis of an extensive catch of plaice according to the sizes of the fish. If, say, some thousands of plaice captured on the same (restricted) fishing ground be individually measured, it will be seen that there are far more fishes of certain sizes than those of the intermediate sizes. Such a method of estimating the ages of the fishes forming a single catch cannot be easily understood without an example, and the diagram* (Fig. 6), which is based on a catch made by the Marine Biological Association off Mablethorpe, will make the reasoning clear. The figures on the vertical line represent the numbers of plaice taken, and those on the horizontal line represent the sizes of the fish. At the point of the curve marked $\mathrm{O}$ a line drawn horizontally shows that about 360 plaice were captured, which had an average length of about $5 \frac{1}{2}$ centimetres (a little over 2 inches); at the point I about 85 plaice were taken with an average length of 10 centimetres ( 4 inches); then at the point II 60 plaice were captured with an average length of 15 centimetres (6 inches). That is to say, in this catch three predominant sizes of plaice were present, 2 inches, 4 inches, and 6 inches. In fact we have three groups or "schools" of fish, each of which resulted from a different year's spawning. The Group O consists of fish less than one year of age, Group I of fishes over one but less than two, and Group II of plaice over two but less than three years of age.

The other method of determining age is that of otolith examination.

* Wallace, Fishery and Hydrographical Investigations, etc., Southern Area (cd. 2670), 1905 , p. 208 , fig. 4 . 
The otoliths are the hard, calcareous stones which are found in the ears of all animals, but which are unusually large in bony fishes. The method was elaborated a number of years ago. It depends on the fact that the growth of the ear-stone or otolith is not regular, but varies from season to season. So also with the bones of the fish, as for instance the vertebræ. If the otolith be examined, even with the naked eye, it will be seen to be built up of concentric layers. Every year a new layer is added to those already laid down, and by counting the number of concentric rings in the otolith, or vertebra, the number of years of age of the fish can be determined. Up to the fifth year of life both

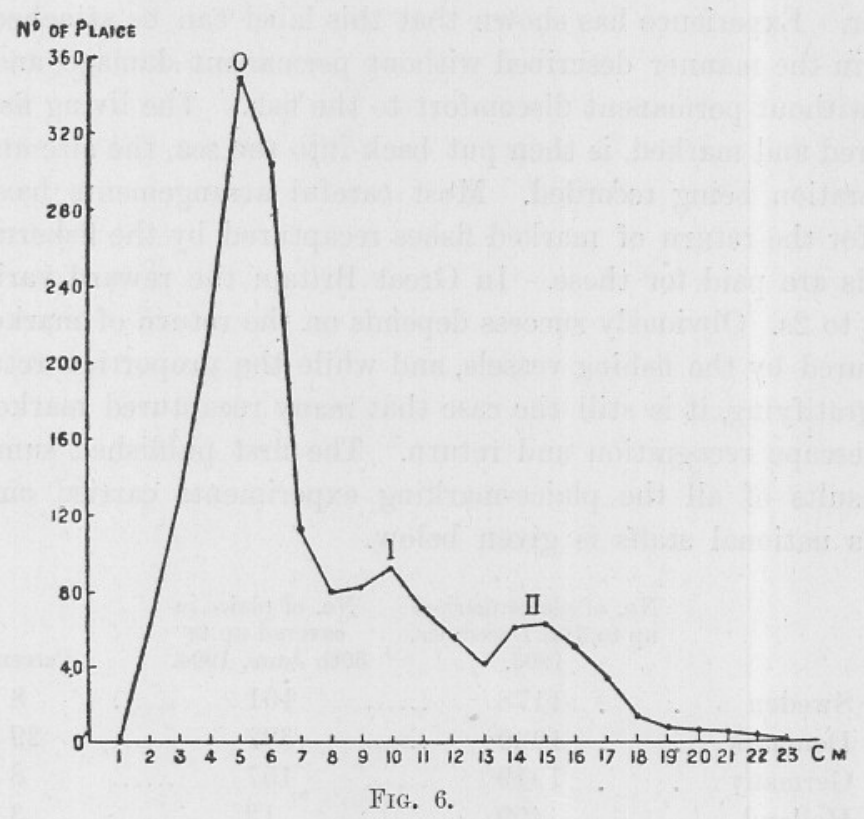

methods are reliable, but after this period the results are somewhat uncertain. By the application of these two methods, particularly the first, results have been obtained in all the countries participating in the International Investigations, and the plaice of different localities are now being investigated, not only with respect to their abundance according to the depth of water, but also with regard to size and age.

A third method of age determination is a direct one, and depends on the marking and liberation of a plaice, and its subsequent recapture. This brings us to the consideration of the fish-marking experiments which have now been carried out on a very extensive scale in Sweden, Denmark, Germany, Holland, and England. This method of investigation is, of course, an old one, and was practised in Scotland by the 
Fishery Board, and in America by the Fish Commission, many years ago. It is only since the inception of the International Investigations, however, that it has been carried out on a scale adequate to the furnishing of reliable and useful results.

Various methods of marking the fish (usually plaice), so as to identify it afterwards, have been practised. In Petersen's method (the one now mostly adopted), a stout silver wire is pushed through the body of the fish just underneath the dorsal fin. One end of this wire passes through a bone button and is looped; the button is on the lower side of the fish. The other end passes through a hole in a brass disk and is also looped; the brass disk is on the upper side of the fish and bears a number. Experience has shown that this label can be attached to the plaice in the manner described without permanent damage, and apparently without permanent discomfort to the fish. The living fish, being measured and marked, is then put back into the sea, the size and place of liberation being recorded. Most careful arrangements have to be made for the return of marked fishes recaptured by the fishermen, and rewards are paid for these. In Great Britain the reward varies from 1s. $6 \mathrm{~d}$. to $2 \mathrm{~s}$. Obviously success depends on the return of marked fishes recaptured by the fishing vessels, and while the proportion returned is most gratifying, it is still the case that many recaptured marked fishes must escape recognition and return. The first published summary of the results of all the plaice-marking experiments carried on by the various national staffs is given below.

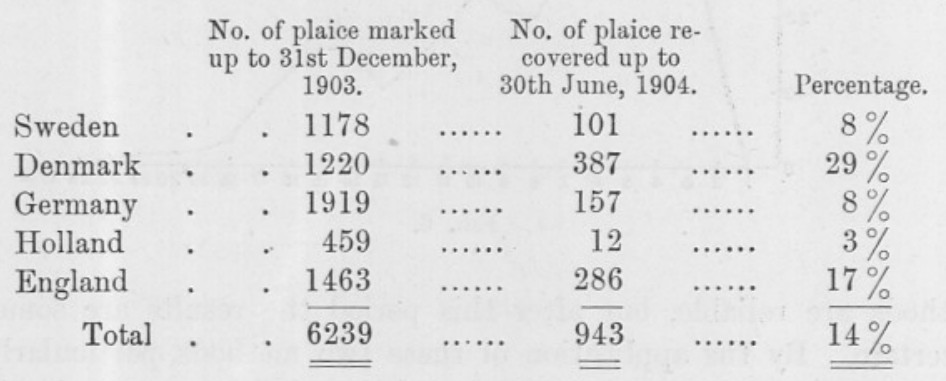

The "percentage" is the proportion of marked fish recovered within twelve months after the date of liberation.

Of course, these returns are very incomplete. A large number of fishes have been marked and subsequently recovered since the end of 1903 , but at the present time the figures are not easily available, and the results have not been collated. The above statement applies to the fish-marking experiments carried on by the naturalists attached to the staff of the International organization. But in addition to these experiments, a large number of plaice and other fishes have been 
marked and liberated (according to the International methods) by the Irish Fishery Branch of the Board of Agriculture and Technical Instruction, and by the Lancashire and Western Sea Fisheries Committee, both experiments being carried out chiefly in the Irish Sea.

The plaice-marking experiments were designed to give information on the following subjects :-

1. The migrations of the fishes.

2. The rate of growth of plaice in different localities.

3. The intensity of fishing.

An obvious objection has frequently been made to the validity of results deduced from such experiments, and is this: the operation of marking injures the fish, and the continuous attachment of a label or mark to the body reduces to some extent its vitality, so that it is probable that the results, whether migrations or rate of growth, obtained from the marked fishes do not represent those changes undergone by unmarked fishes. The force of the conclusions depends on the assumption that a marked fish behaves normally, and this is questioned. The objection, which is an a priori one, probably has some force, but the general opinion of those who have had experience of fish-marking experiments is that the operation, if carried out carefully, has little or no influence on the health or habits of the fishes dealt with.

The migrations of the marked plaice are naturally the most interesting of the results obtained from these experiments. In stating the more prominent facts observed, one cannot, however, be too cautious Only the results of one complete year's experiments have so far been tabulated and discussed, and it is most essential that these should be confirmed by the further experiments that have already been made. A plaice is an animal possessed both of volition and intelligence, and its movements in the sea must be expected to be at times of an entirely capricious nature. It is only by the study of results of extensive and repeated experiments that one can hope to eliminate such accidental or capricious migration results, and obtain an expression of the average movements of large numbers of fishes. Bearing this in mind, we may state the results at present apparent. Young plaice-that is, fishes up to 8 inches in length-do not migrate to any marked extent. These fish remain on the shallow-water areas immediately adjacent to the places where the first year of their life has been spent. Any one who observes attentively the shallow pools which have been left by the receding ebb tide on almost any of the extensive sandy flats on the coasts of England will be able to see numbers of small plaice and other flat-fishes there during the months of June or July. At that time these little fishes have just recently completed their metamorphosis from the 
larval to the post-larval stages, and are little larger than one's thumbnail. As they grow they gradually move further out into deeper water, but for this first year of their life and the next one they do not travel very far from the shore on which they may first be found. After they have entered on the third year of life, however, their more lengthy migrations begin. These are influenced to a very great extent by the nature of the sea area in which they find themselves. Thus the results obtained by the Danish naturalists* show that the plaice marked and liberated off the coast of Denmark travelled for the most part along the shallow water adjacent to the coast (Chart X) or, when liberated, migrated inwards toward the shore. But other fishes travelled outwards into deep water. There is little doubt that these movements depend to some extent on the season. Off the Danish North Sea coast there is a distinct tendency for plaice to move from deep water towards the shore during April, May, and June, but later in the summer they appear to move off-shore again into deeper water and to spread over a somewhat wide area.

In the case of the English experiments carried out in the southern part of the North Sea, the change of the migration path according to the season is also displayed. In the charts giving synoptic representations of the experiments $\dagger$ this is well shown. South of latitude $53^{\circ} 30^{\prime}$ in the North Sea, it may be said that plaice for the most part travel to the south during the winter and to the north during the summer. This applies to the larger fishes dealt with. The smaller fishes hardly travel at all. Sometimes, in the case of the larger fishes, the distance travelled is very considerable. Thus one plaice of 13 inches in length, liberated in December, 1903, in the middle of the North Sea, nearly in the latitude of Grimsby, was found about three months later in the English Channel, having travelled in the interval a minimum distance of 175 miles. Other instances are recorded of long migrations made by marked plaice, and generally it may be said that the larger fishes travel further and more rapidly than the smaller ones, and in addition frequent deeper water. But we meet with puzzling exceptions to this general rule. Thus a medium-sized plaice liberated by the Lancashire naturalists in the preserved waters of the south coast of Scotland was found in the same place nearly two years afterwards, having in the interval probably not left the bay in which it was first found,

To deduce the rate of growth from marking experiments is a simple matter. The fish being marked and measured is again measured when

\footnotetext{
* See charts X-XII, Meddelelsen Komm. Havundersög., Fiskeri, Bd. i. Nr. 2, 1905.

† Garstang and Borley, Fishery and Hydrographical Investigations in the North Sea, etc., Southern Area (cd. 2670), 1905.
} 
recaptured, and the difference in length is the growth during the interval. As might be expected, there are considerable differences in the average results so obtained. It now appears, from a discussion of these experiments and others, that no average growth rate can be laid down which applies to all plaice in the British and continental fishery area. Some of these differences are summarized by Garstang.* On the Horn Reef grounds, off the coast of Denmark, the greatest rate of growth indicated by plaice in the course of a single year was about 5 centimetres (about 2 inches). On the other hand, certain plaice caught on these grounds, and on the east coast of England, and then transplanted to the Dogger Bank, showed a much greater increase in length. In the case of some of these plaice, the growth in one year was as much as 14 centimetres (nearly 5 inches). Analogous differences in the rate at which plaice grow are met with in very many of the experiments made.

The intensity of fishing on any fishing ground can be deduced from these marking experiments. If we capture (say) 1000 fishes and mark and liberate them on the ground from which they were taken, then the proportion of these 1000 fishes which are recaptured within one year from the date at which they were liberated is an indication of the degree to which this ground has been exploited by the fishermen in the course of the year. For the 1000 marked fishes may reasonably be assumed to have spread uniformly over the fishing ground in question; and if the fishermen capture (say) 250 of them during the year, there seems no escape from the conclusion that they have also captured 25 per cent of all the plaice, of the same range of sizes as the marked fishes, which were originally present on the ground. Of course, such deductions must be made very cautiously and must depend on the consideration of fairly large numbers of fishes. But, remembering this, it is certain that in this method we have a fairly satisfactory means of ascertaining how far fishermen reduce the fish population of a fishing ground, in the course of their ordinary operations. There is only one other way of obtaining this information : by a consideration of the number of eggs of the species of fish considered which are produced on the ground during the spawning season, and this method is very unreliable. Nevertheless, such an estimate, made by Victor Hensen in the case of the West Baltic cod and plaice fisheries in $1895, \uparrow$ agrees very well with the average results of the fish-marking experiments. Naturally the intensity of fishing on the various grounds varies very greatly. $\ddagger$ On the fishing grounds of the North Sea, Skagerak,

* Rappts. et Proc.-verb., vol. iii., 1905, app. H, p. 14.

† See Jenkins, Trans. Liverpool Biol. Soc., vol. xv. p. 312, 1901.

¥ See Garstang, Rappts, et Proc.-verb., vol, iii. app. H, p. 10, 1905. 
and Cattegat it varies from 4 to 56 per cent. We may reasonably conclude, eliminating exceptional circumstances, that the intensity of plaice fishing on the North Sea fishing grounds varies from 10 to 25 per cent. That is to say, that man, for his own use, removes annually from the sea from one-tenth to one-quarter of all the marketable plaice which are annually produced by the natural reproduction and growth of the species.

How significant these results are from the point of view of the regulation of the plaice fishery and its further exploitation and improvement will easily be seen. The question now arises how far this process of exploitation of the (say) plaice population of our seas can go on without progressive impoverishment of the fishing grounds. There must be some limit up to which these fishing grounds can be depleted without undergoing injury; that is, without making them less productive in the future. To discover this limit is the aim of this portion of fishery investigation, and it then remains for the Governments concerned so to legislate that it should not be exceeded. In no way can this knowledge of the extent to which the resources of the sea can be strained be attained than by scientific investigation on the lines indicated and by the careful consideration of reliable commercial statistics. When the International Investigations are completed and thoroughly discussed we may hope for much more knowledge of the conditions of this problem than we at present possess.

Then in the result that plaice are so very variable in growth we have a factor of no less significance for the legislators.

When we find that the growth rate of plaice on a fishing ground is small, we usually find that the number of small plaice present on that ground is unusually large. There is, in fact, this relation between abundance of plaice and their size, that the more numerous the fish are on a certain ground the more slowly they grow. It is a question of the available amount of food for the fishes that we have to consider. Where the number of mouths is small there is all the more food for them and the fishes grow quickly; on the other hand, where the population is large and the stock of food not proportionately large, the fishes are less well nourished and they grow slowly. How significant this question is when the protection of immature plaice (and other fishes) is being considered is very apparent. In the past the protection of immature fishes per se has been considered as of undoubted value for the fisheries.* Now we must remember that to "protect" by legislative restrictions the immature fishes of particular fishing grounds

* In spite of the declared opinion of Huxley, who deprecated such legislation if incautiously embarked upon (Life and Letters of Thomas Henry Huxley, vol. ii. p. 234, 1900). 
may be positively detrimental to the industry generally. The lesson that such investigations of crowded fishing grounds, with large numbers of small plaice growing slowly, teach is the necessity for transplantation. Long ago Petersen pointed this out in the case of the Limfjord plaice fisheries, and the International Investigations point this advice more clearly. Garstang, in a remarkable series of experiments carried on on the effect of transplanting plaice from overcrowded to less frequented grounds, has shown how useful such measures might conceivably be.* It was observed, as we have seen, that plaice on the "small-fish grounds" off the coast of Denmark or off the east coast of England grew slowly in comparison with plaice on the more open and less crowded grounds on the Dogger Bank. A number of plaice were therefore captured on these grounds and taken across to the Dogger, where they were marked and liberated. The growth rates of the fishes on the latter locality could then be compared with the same growth rates on the localities from which the fish were originally taken, and which had been determined by other experiments. About 40 per cent of the fishes transplanted to the Dogger were subsequently recaptured, and these showed a remarkably higher rate of growth than obtained on their original localities. Whereas on the Horn Reef grounds-a good example of a crowded plaice ground-the fish increased in length about $1 \frac{3}{4}$ inch in the course of a year, the same fishes on the Dogger added about 5 inches to their length in the same period.

Whether such transplantation operations could be carried out on a really large scale, and would be productive of such results as would justify the expenditure of public money on this work, is a question which is discussed at some length by Mr. Garstang. The practical difficulties attending such work are of course very great, and one can see that considerable organization of methods would be required. Conspicuous commercial success has attended similar operations carried out by the Lancashire and Western Sea Fisheries Committee; $\uparrow$ but the practical details of the transplanting operations, which in this case concerned mussels, were of course much more easily dealt with.

\section{The life history of the Cod. $\ddagger$}

With respect to the natural history of the cod, we find that the investigations are still very incomplete. A very considerable amount of material for the study of the life history of this fish has been collected by the Norwegian, Danish, and English research vessels, but

\footnotetext{
* Garstang, Fishery and Hydrographical Investigations in the North Sea, etc., Southern Area, p. 45, 1905 .

+ See Scott and Baxter, Report Lancashire Sea Fisheries Laboratory for 1905.

¥ Hjort and Petersen, Rappts. et Proc.-verb., vol. iii. 1905, app. G.

NEW SERIES, VOL. VII. NO. 5 . 
we are still far from knowing enough to enable us to follow out the habits and wanderings of this important food fish. One may confidently expect, however, that the result of the International Investigations will be to make clear the principal features in the life history of this fish. The following account is based on the work so far published:-

The cod has not the same importance for the fisheries of Britain as for those of Norway. Over the whole North Sea the fish occurs and is caught, but it only forms a part of the general catches of the fishery fleets. In Norway, however, it is the fishery, and the cod has for the fisheries naturalists of that country a degree of importance which has justified considerable research. The great cod fishery in Norway is that which is followed in the spring of the year on the coastal banks from Lofoten to Tromso. The line-fishery there for spawning cod, the "Skrei" fishery, sometimes obtains great dimensions. In the spring of the year the adult fish frequent the coastal banks in great shoals. They are found almost exclusively on these grounds. At this time they are spawning, and it is when the fish are most numerous that the pelagic eggs at the surface of the sea are also present in greatest abundance. The Norwegian research vessel, for instance, took as many as $5800 \mathrm{cod}$ on 17,800 hooks in one day, and during the entire spawning season of the same year about one and a half million of cod were caught by the entire fishing fleet. Experimental fishing operations were carried on over a wide area, but the fish were restricted to a comparatively small ground. On the Lofoten fishing grounds the Norwegian naturalists found that the characteristic spawning size of the fish was about 28 inches. In the North Sea the cod spawns when about the same size. On the other hand, very different conditions obtain in the Cattegat. Petersen found considerable numbers of cod spawning there when no larger than about 12 inches.

On most cod grounds investigated the early part of the year to the spring is the period when spawning takes place. In the Lofoten fisheries the spring is the spawning season, and the same is the case in the North Sea. In the Cattegat, spawning takes place earlier in the year. In the Irish Sea cod spawn in the spring. But a remarkable exception to this general behaviour of the cod was first demonstrated by Fulton,* who found when fishing from the Scottish International research steamer Goldseeker that cod might spawn in the North Sea in the autumn. In August of 1903 both fertilized and developing cod eggs were found in the townets, and ripe and mature cod were taken in the trawl. The discovery was quite novel. Hitherto an autumn spawning was only known in the case of herring, and the well-known spring and autumn

\footnotetext{
* Publications de Circonstance, No. 8, 1904.
} 
or winter and summer herring spawning has been explained by assuming the existence of two "races" of fish, one spawning in the spring and the other in the autumn. Whether or not such is also the case with the cod must be left for future investigation.

On the Lofoten cod fishing grounds, as in the North Sea, the cod frequents the coastal shallow water when about to spawn. The striking figures given by Hjort in the paper quoted show that the eggs were present in extraordinary abundance on the surface of the sea over these banks. In the waters of the channels between the banks much smaller numbers of eggs were taken out at sea, and generally over the surface of the open Norwegian sea the cod eggs were most scanty, or altogether absent. Just where the spawning fish were present on the bottom, there the resulting eggs were found. The eggs were very slowly distributed over the sea area, so slowly that in the meantime incubation had proceeded and resulted in the hatching of the pelagic fry. Many fishery experiments were made by the Norwegians to determine the range of distribution of the cod fry of different stages and at different seasons, and these results are very interesting. Hjort's Fig. 6 in the paper referred to shows this in a striking manner. The area over which the eggs were distributed extended but little out to sea from the banks. Outside this again, but a little later in the year (June and July), were to be found the young cod, at this period up to about 1 inch in length. Then in August to September the area over which the fry was distributed had greatly increased. Young cod up to about $3 \frac{1}{2}$ inches in length were found in the Norwegian sea as far from land as 120 nautical miles. During the interval between spawning in March and April and September, the cod fry had slowly drifted off-shore and to the north. All this time they were pelagic in habit-that is, they were found near the surface of the sea-but when attaining this length they began to seek the bottom. This habit differs greatly from that of the young cod in the North Sea. There the pelagic mode of existence is abandoned, and the little fish seek the bottom when little over 1 inch in length.

Hydrographic conditions in the sea are most probably the causes of these differences in the habits of the cod. The dispersal of the eggs and young fishes is due to surface-drifts and currents. The assumption of the bottom-living habit of the young cod is no doubt also dependent on the temperature, among other conditions. Thus over the greater part of the northern North Sea area young cod are hardly ever found at the sea bottom. There a bottom temperature of $6^{\circ}-7^{\circ} \mathrm{C}$. holds good all the year round. With regard to the distribution of the cod in its first year of life, a great amount of material has been collected by the International exploring steamers, and when this is fully worked out we may expect to possess a very complete knowledge of the manner 
in which hydrographic conditions influence the distribution of the fish over the North European area.

\section{Statistical Investigations.}

If a knowledge of the life histories of the edible fishes is essential for the proper control of the sea-fishing industry, an exhaustive knowledge of the statistics of the fisheries is no less indispensable. Fishery authorities, recognizing the value of statistical knowledge, have almost invariably created organizations for obtaining this information, and one may say that the success of these has been proportional to the experience of the authority. Thus in Scotland, where a strong fishery board has now existed for nearly a century, a system of collecting fishery statistics has slowly been evolved and is probably the most perfect in existence. In England, on the other hand, where the fishery authorities are of much more recent origin, statistical knowledge of the industry is still very imperfect. By the statistics of the fisheries has usually been understood a knowledge of the quantities and values of the marketable fishes sent to the public markets from month to month throughout the year; with also a knowledge of the numbers of fishermen and of the fishing vessels belonging to various classes. Such is the statistical information relating to the sea-fishing industry which is published in the official documents of the authorities. As the industry has developed and the need for legislation become apparent, it has gradually become evident that such information is far from being adequate.

Official fishery statistics have in fact been based almost entirely on the material landed on our shores, without regard to the places and methods where, and by means of which, this material was obtained, and it is very evident that such information affords only an imperfect view of the operations of the fishing vessels. An exhaustive system of statistical information would inform us where the fishing vessels had been fishing from day to day throughout the year; what methods they had employed; what proportion of the time of their voyages had been spent on actual fishing operations; what kinds and quantities of fish they had caught, and on what particular fishing grounds these had been captured. Then we ought also to possess exhaustive knowledge of the personnel of the industry, as well as that of the kinds, tonnage, value, etc., of the vessels employed. Such statistics of the fishing industry have not, so far, been furnished by any fishery authority. But even if we did possess them, they would be inadequate for a proper understanding of the conditions of the industry. The figures relating to the quantities of fish captured and landed would be based on the working of certain 
kinds of fishing apparatus-trawls, lines, drift nets, etc. These are designed to capture only certain kinds and sizes of fishes, and it is these that would be represented in the returns. What the trawl, for instance, captured that was not utilized would not be represented in the statistics. Then the condition of the fishes, as regards spawning or characteristic food, for instance, would not appear. We must remember also that commercial fishing apparatus would not give us any knowledge of the fish population of the sea in general. The capture of anything whatever, except those animals which are to be placed on the market, is not desired, and the fishing nets are constructed with this object. To know the condition of the fishing grounds, we must employ other methods in addition to the study of the commercial products of fishery. That is to say, exploring vessels equipped with other fishing apparatus than those used by the fishing fleets must be employed, and the statistics obtained by these vessels should supplement the commercial figures.

Here we trench on the purely scientific investigations of the fisheries, and, indeed, there is no real dividing line between these two departments of research. They must be followed in conjunction, the one supplementing the other. When the International Investigations were devised this was recognized, and the synthesis of both statistical and purely scientific researches, the two being controlled by the same authority and carried out by the same organization, was elaborated. A large portion of the results of the investigation published so far consists therefore of statistical studies and discussions.

A very good example of the scientific study of fishery statistics is furnished by Henking's paper* dealing with the statistical material of the Deutschen See-Fischerei-Verein. The latter body is a private fishery research society, which, however, enjoys imperial recognition and patronage, and a considerable financial support from German state funds. In the course of the years 1902-5, the See-Fischerei-Verein organized a system of collecting statistics from German steam fishing vessels. Not only does the information given to the society contain the quantities and kinds of fish caught, but it also gives the regions of the North Sea exploited by these vessels. In the year 1904 this system of statistical collection had been completed, so that the See-Fischerei-Verein now obtains the results of the fishing operations of the entire fleet of German fishing steamers.

Henking divides the North Sea into two areas: (1) the northern North Sea area, which comprises the Great Fisher Bank, the Long Forties, and the portion of the North Sea plateau which lies to the

* Rappts, et Proc.-verb., vol. iv., 1905, app. F. See also Betheiligung Deutschlands an den Internationalen Untersuchungen, Bd. i. 
north of the grounds mentioned, as far to the west as Scotland; and (2) the southern North Sea area, which comprises the banks in the German Bight. Then we have in addition (3) the region of the Skagerak. The catches of the steamers are expressed as average numbers of pounds of fish caught per steamer per day. These average catches are studied from month to month. Curves are also given by Henking which show clearly how the fishing varies from month to month throughout the year. The result of such analyses of the catches is the defining of "Fishery Periods," which are periods of time during which some particular fish is abundant on a certain ground. Such fishery periods are of course familiar things, and one need not give as instances more than the well-known herring fishery periods of the east coast of Britain or the cod fishery periods of the Norwegian Lofoten Banks. A fishery period is caused by the immigration of great numbers of fishes into relatively restricted areas. Then begins the commercial fishery, which ends with the emigration of the fishes from the fishing ground in question. When the regular variations in the amount of fishes brought from the (known) fishing grounds are studied from month to month, it is seen that the existence of such fishery periods applies to almost every kind of edible fish studied. These fluctuations in the abundance of fish on the different grounds from time to time throughout the year are due to real migrations of the fishes; either to their migration to different fishing grounds or to their dispersal through the upper layers of the sea, where they are without the reach of the trawl. "In view of the considerable material which forms the basis of our review, it can hardly be considered that the fluctuations in the curve of the catches is referable to the captains of the boats wishing to avoid the capture of certain species at certain periods of the year; there remains no other possibility, therefore, than that the number of fish in front of the trawl has actually varied."*

'Into Henking's details of the migrations of food fishes in the North Sea we cannot of course enter, and the reader is referred to the charts of results. These curves when plotted for different regions of the North Sea and Skagerak show that extensive movements of fishes go on. The hake, for instance, is such a migratory fish. For the first three or four months it is hardly at all taken in the North Sea or Skagerak. Then it appears "in ever-increasing numbers, perhaps with the inflow of Atlantic water." The shoals spread over the northern North Sea and appear in dense masses in the Skagerak in June. In that month the fish is relatively scarce in the southern North Sea. Then later in the year, August to September, when the fish has become less abundant in the Skagerak, it increases in abundance in the northern North Sea

\footnotetext{
${ }^{*}$ Henking, loc. cit., p. 18.
} 
area, indicating the emigration southwards of the shoals previously present in the Skagerak.

Such a mass of statistical data provides only a "representative sample" of the fishing carried on over the region investigated by Henking. Even though the study professes to deal with the catches made by all the German fishing steamers, it must be remembered that these form only a portion of the whole fishing fleet exploiting this area. Obviously such a method of studying the operations and results of the fishing vessels can be wholly satisfactory only when all the vessels, steam trawlers, liners, and smacks, can be made to furnish returns of their catches, stating the quantities and kinds of fishes caught, the areas of capture, and the duration of the fishing. If we could obtain this information, and have it worked up under the direction of an International Fishery Board, we should then be in possession of knowledge of incalculable value for the regulation of the industry.

But a scheme of statistical collection of such nature and magnitude is apparently Utopian only, when we consider the present organization and resources of official fishery authorities. The next best method is that which has been followed by some of the organizations in connexion with the International Fisheries Council. Since it is impossible to obtain figures representing the fishing results of all the North European vessels, we have to be content with results which represent the fishing of large and important fleets having their head-quarters at various fishing centres. If a large number of vessels which fish over a wide area can be induced to furnish the results of their fishing, then we possess a series of data which may be taken to represent the fishing carried on by all the fleets. The larger the number of vessels supplying returns, the more reliable, of course, are the conclusions made. Such is the method of studying the fluctuations of the fisheries on the more important fishing grounds which was first suggested by Fulton in his well-known paper in the Report of the Scottish Fishery Board for 1901; and which has been adopted by Redeke for the Dutch North Sea trawlers, by Henking for the German steam fishing vessels; and which may be studied at its best in the Reports on the fishing results of the Aberdeen fishing fleets by D'Arcy Thompson and Fulton.* Since 1901 the Scottish Fishery Board has collected such statistics, and when the International fishery researches began the figures obtained were dealt with by the International Council in connexion with the other investigations.

At the present time nearly all the steam liners, about two-thirds of

" See D'Arcy Thompson, "Aberdeen Trawling Statistics" ; Fulton, "Distribution and Seasonal Abundance of Flat-fishes in the North Sea " ; Fishery and Hydrographic Investigations in the North Sea (cd. 2612), 1905. 
the steam trawlers, and a number of the sailing trawlers landing catches at Aberdeen furnish voluntary returns as to the places where they have been fishing, the number of hours fishing, the number of hauls of the trawl and number of lines shot. The quantities of fish landed by these vessels at Aberdeen, with respect to the market grouping in sizes, are obtained by the officers of the Fishery Board. The figures so obtained are collected and discussed by the statistical clerks and others on the staff of the Scottish section of the International organization. No details of individual catches are published, only abstracts, and the statistics themselves are made public long after the actual fishing has taken place. There can be no commercial use made of the information given by the masters of the vessels by their rivals in trade : an important consideration, since the information is voluntary and can be withheld.*

In dealing with the figures of fish captured by the Aberdeen fleets, Fulton refers the catches to the areas in the North Sea in which they were made. For this purpose the North Sea north of parallel $50^{\circ} \mathrm{N}$. and $\mathrm{E}$. of meridian $6^{\circ} \mathrm{W}$. is divided up into forty-eight squares, each of which corresponds to one degree in latitude and two in longitude. When a vessel returns to port, her master informs the collectors of statistics what course he has steered on his voyage out from port, where he has fished, and the number of hours trawling on each ground or the number of lines shot (if he is a liner). The results of the voyage, when tabulated by the statistical clerks, show for the trawling fleet during January (for instance) the average quantities of each kind of fish taken per 100 hours trawling on each of the numbered areas, or the average quantities of fish taken per 100 lines shot.

By this method a very great mass of information has been accumulated and published by the International organization. Fulton's paper already referred to deals with the flat-fishes taken by the Aberdeen trawlers-turbot, brill, halibut, witch, megrim, lemon-dab, plaice, and dab. The abundance and fluctuations of each of these fishes on the northern North Sea grounds from month to month are studied with reference to particular fishing areas. The fluctuations are represented by tables and charts showing graphically the variations on particular areas throughout the year. Into the details of this most interesting study we cannot, of course, enter; only one or two of the main conclusions can be alluded to here. A result that appears persistently throughout the discussion

* It is therefore erroneous to state (see, for instance, the House of Lords debate, 25th June, 1906) that we have by the publication of these figures handed over information to German fishermen which is made use of to our detriment. Even if these figures could supply such information, one can hardly imagine that the German fishing industry is so well organized that trawl owners or fishing-boat masters study English scientific journals; any more than that English or Scotch owners or masters study, for instance, the German Mittheilungen des Deutschen See-Fischerei Verein; or that state fishery intelligence departments exist in either country which study this information and supply it to the fishing industry. 
of these statistics is the "complementary fluctuations" among different flat-fishes inhabiting the same ground. In the case of one particular fish the abundance varies, of course, with the season; but the periods of the year at which a fish is most abundant differ for many of the species considered. In one area considered, for instance, megrim were most abundant about May, plaice in April and September, witches in June and July, halibut in April, and lemon-dabs in September. Thus the scarcity of one species was compensated for by the abundance of one or more others, so that on any one fishing ground the general abundance of all the flat-fishes was maintained throughout the year at roughly the same level. In the case of nearly every one of the fishes studied the fluctuations from month to month exhibited undoubted regularities. It was nearly always possible to deduce that on each fishing ground there was one month during which each species of fish was present in greatest abundance. This maximum in each case corresponds.with the spawning season and indicates an aggregation of the fishes on particular areas for the purposes of reproduction. Following this spawning maximum of abundance, the period of which, of course, varies with each kind of fish, is a period of relative scarcity. Then occurs a secondary maximum some time in the autumn, when the fish is again abundant, though usually not so abundant as in the spring or summer spawning maximum. Then in the winter there is often another period of relative scarcity. These remarks apply to the study of the fishes present on each particular fishing area throughout the year. How the abundance of each kind of fish is distributed throughout all the separate fishing areas may be seen by considering the charts of the fishing grounds published by D'Arcy Thompson in the paper referred to above. These show for each month in the year the average amounts of cod, ling, saithe, hake, haddock, and whiting caught on each area per 100 hours trawling by the Aberdeen trawling fleet. Their charts simplify greatly the study of the statistical data. The variations in fish abundance displayed by them are interesting and well worth study by the reader.

The aim of the master of a fishing vessel is, of course, to get as much fish as possible. Therefore he does not always frequent the same grounds, but fishes from place to place over the North Sea, following the fish shoals, getting varying catches on the various grounds. At one time one kind of fish may predominate, during another month other kinds. Long experience, and many fruitful or fruitless experiments, have taught him where and when to expect good catches. If this practical knowledge of the fishermen could be systematized, sifted from error, and recorded, we should possess a knowledge of the seasonal fluctuations and migrations of the fishes which, supplemented by the 
knowledge of their life histories slowly acquired by the naturalist, would provide the material for the legislators. Bearing this in mind, the reader will see how valuable would be a knowledge of the places where the fishing fleets have worked from month to month throughout the year, for when considered along with the statistics of the fishes caught by them, this information would show us how the vessels had been following the fish from fishing ground to fishing ground. In Thompson's paper, already referred to, a beginning has been made of the collection of information of this kind. The twelve beautiful charts* of the northern North Sea which are contained in this paper show from month to month the positions of the Aberdeen trawling and lining fleets. These show how the fishing vessels move from place to place, sometimes aggregated on a relatively small area, at other times widely dispersed. It is the migrations of the fishes forming the objects of the fisheries that are the cause of these movements of the fishing fleets, and the latter are, to some extent, a representation of the former.

I will refer to only one more statistical study made by the International organization. The reader will find in volume iii. of Rapports et Procès-verbaux a comprehensive survey of the fishery statistics of the various participating countries, which will show him how very deficient our knowledge of the economics of the industry is, and how great is the need for the co-ordination of the statistical bureaux of the North European fishing countries and for improvement in the means of collection. If as one result of the International Investigations a central statistical office could be instituted, which would receive, collate, discuss, and publish the statistics of the North Sea fisheries, a store of knowledge of incalculable value to the fishing industry would gradually be accumulated. When the International Investigations began, the most prominent question, in this country at least, was that involving the effects of capture of small plaice on the so-called eastern grounds of the North Sea. The material for the treatment of this question did not then exist, and its acquisition was one of the aims of the International Fisheries Council. In 1904 the various Governments concerned began systematically to collect statistics of the sizes of plaice landed by their fishing fleets. In volume iv. of the Rapports et Procèsverbaux the first results of this work are published, though previously the English Board of Agriculture and Fisheries had instituted such investigations with reference to the Immature Fish Bill then before Parliament. $\dagger$ In the paper $\$$ referred to is contained a summary of the

* D'Arcy Thompson, Fishery and Hydrographical Investigations in the North Sea (cd. 2612), 1905, p. 352 .

+ See Archer, Report of the Committee on Sea Fisheries Bill (H.L.), 1904.

\# Kyle, "First report on the statistical material received by the Bureau regarding the quantities of small plaice landed in the various countries," Rappts, et Proc.-verb., vol. iv., 1905, app. C. 
returns made by England, Holland, Germany, Denmark, and Belgium with regard to the quantities of small plaice landed in these countries. These returns are, of course, very imperfect, but the result giving the proportion of small plaice to the total quantity landed is probably approximately correct. About $2 \frac{1}{2}$ per cent of the plaice landed in Holland and about 1 per cent of the plaice landed in England were under 8 inches in length, an estimate which does not greatly encourage the pessimistic view held in various quarters as to the detrimental effect of steam-trawling upon the plaice population of the North Sea.

\section{The connexion between Hydrographic and Biological Phenomena in the Sea.}

We have seen that there is a well-marked periodicity in the hydrographic changes taking place in the sea. When the temperature and salinity of the sea water are regularly determined, it is found that the variations are not irregular or casual ones, but are repeated with a certain amount of regularity from year to year. At any one place in the seas of Northern Europe the temperature of the water gradually rises from a minimum some time in the winter or spring, to a maximum in the summer or autumn; and so also with the quantity of salt in the water; this too varies with more or less regularity, though the maxima and minima may not correspond with those of temperature. Then we have also seen that there is an analogous periodicity in the fisheries of the same area. These are not carried on with perfect regularity all the year round. At certain times in the year different fisheries are predominant. For any one fishing area there are seasons in the year which are characterized by the abundance of a certain kind of fish. Herring fisheries, cod fisheries, sole fisheries, and others have their seasons, which are repeated from year to year with a certain uniformity. Leaving aside for a moment the commercial fisheries, we find that the same periodicity of occurrence and abundance also obtains with the microscopic life of the sea. The waters of the sea always contain a certain amount of drifting microscopic life, bacteria, diatoms, protozoa, cœlenterates, and the eggs and larval forms of the larger animals living at the sea bottom or swimming about in the water. If the occurrence and abundance of this plankton are studied throughout the year, it will be found that it too is not always the same, neither in nature nor quantity. There is a more or less regular sequence of forms of animal or vegetable life, each of which has its maximum and minimum of abundance. Further, if the reproduction of any animal or plant in the sea is studied, it will be found that the breeding season is periodic, and occurs with very great regularity from year to year at about the same 
time. All these changing phenomena-the temperature and salinity of the sea water, the occurrence and abundance of different planktonic species, and the reproductive phases of all animals and plants in the sea - occur from year to year with a certain periodicity. The later direction of fisheries research has been to correlate them and to find out how the one phenomenon depends on the other. More precisely, one of the main objects of the International Fishery Investigation has been to determine in what manner hydrographic changes in the sea are connected with the productivity of the various commercial fisheries.

In all cases plankton observations have been carried on simultaneously with the hydrographic work. The plankton investigations consist of periodical fishing of the sea over wide areas, and both at the surface and at deeper levels, with fine-meshed silk nets, so designed as to eatch all but the very smallest organisms in the water. As a rule, these plankton observations have been so carried out as to secure only samples of the kinds of species in the sea, but in some of the countries quantitative observations have been made; that is, the "townets" are designed to filter a known quantity of water, so that if the numbers of individuals of each species caught are determined, it can be estimated how many organisms of each species were present in a certain bulk of sea water; for instance, in a column of water one square metre in section and extending from the bottom of the sea up to the surface. These quantitative plankton observations are the most laborious which have been included in the International programme, and the results obtained so far are not yet fully worked out and discussed. In the ordinary plankton investigations, only the kinds and relative abundance of the various organisms present have been determined. These qualitative plankton observations have two main objects: (1) to ascertain the sequence of occurrence and abundance of planktonic organisms. Among these are, of course, the eggs and young stages of fishes, and the determination of the occurrence and abundance of these from place to place, or time to time, has obviously the utmost importance in the study of the life histories of the fishes. Then (2) the plankton observations are also of use in confirming the results of the hydrographic researches. The main object of the latter is to ascertain the movements of bodies of water of different origins, by a consideration of their temperatures and salinities. But oceanic streams and currents have also characteristic plankton organisms, and the recognition of the latter is of material value in the determination of the origin of the current.

In any part of the sea of our coasts there is a regular sequence in the occurrence of the organisms of the plankton. It would be quite impossible to give this in detail for the various regions investigated by the International steamers. Speaking quite generally, we should find such 
a general scheme as the following: At the beginning of the year there is little variety in the composition of the plankton, and it is relatively scanty in amount. But towards March and April it becomes astonishingly rich and abundant. Diatoms are present in great quantity, and we have the eggs and larvæ of the fishes which are then spawning. A little later on the larvæ of hosts of invertebrate animals appear, and towards the summer these and the fish eggs and larvæ begin to decrease. About this time also the diatoms occur in least abundance. Cœlenterates, medusæ, siphonophores, medusoid forms of hydrozoa, and protozoa such as Noctiluca and Ceratium occur in great abundance. Then in the autumn there is again a luxuriance of diatoms, these organisms attaining their second yearly maximum of abundance, which, however, is usually less than the spring maximum. As winter approaches, the plankton again becomes less varied and abundant.

Then we have "swarms" of organisms appearing in the plankton. Over restricted areas of sea one kind of organism may be present almost exclusively, and this swarm may drift over a large extent of sea. Many such instances are recorded in the International publications. Even if the usual varied plankton is found, we may be able to trace the (passive) migration of certain characteristic constituents from place to place. An excellent example of this is to be found in the distribution of the jellyfish Muggicea in the waters of the English Channel and Irish Sea in 1904. The plankton observations made by the Marine Biological Association in that year* show that a shoal of these animals coming up from the Bay of Biscay reached the English Channel about April. Dividing, one part of this shoal entered the Channel, and by the beginning of September had travelled as far east as Portland, after which month it gradually retreated to the west. The other part of the shoal rounded Land's End, and by the end of September had gone as far north as Cardigan Bay and South Arklow. About this time a southerly drift of water from the Irish Sea had begun to divide the shoal, and part was driven to the south and west coasts of Ireland. By the end of November the shoal had reached far up the west coast of Ireland, and was observed in Galway Bay.

Now the distribution of this shoal of animals depended on three things: (1) the true drift of Atlantic water towards our shores, (2) the superficial drift of the water due to winds, and (3) the reproduction of the animals. Probably the large hydrographic phenomena which we have already considered had not much to do with the migration of the shoal. But in another plankton study carried out by the International vessels $\dagger$ we have a clearer instance of the conveyance of the plankton

* See Gough, Publications de Circonstance, No. 29, 1905.

† See Damas, "Notes biologiques sur les Copepodes de la mer norvegienne," Publications de Circonstance. 
by the great oceanic streams. In the Norwegian sea occur enormous numbers of the copepod crustacean Calanus finmarchicus. This animal has its home in the colder sub-Arctic regions, and does not, like so many other planktonic organisms, reach the Norwegian sea from the Atlantic. In the spring of the year the adults are brought to the south by the current which flows to the south-east of Jan Mayen and Iceland - the East Icelandic Polar stream. Reaching the region of the FaeroeIceland channel, spawning takes place, and the young are then carried to the north along the coasts of Norway by the Atlantic north-flowing stream. In these waters the young calani, living among immense quantities of diatoms, peridinians, and other forms of plankton life, grow and form the great shoals of Calanus finmarchicus which characterize these waters. It is the salt water of the Atlantic stream which, to some extent at least, favours the spread of this crustacean.

The precise manner in which changes in temperature and salinity affect the abundance of planktonic organisms is, of course, very obscure. In many cases the connexion is doubtless an indirect one. We know that in the sea the larger animals prey upon the smaller, and that the ultimate food organisms are the diatoms (and other organisms with a similar method of nutrition). That is to say, every living animal in the sea depends, in the long run, on the diatoms, which form the "pastures of the sea." A cod, for instance, may feed on dabs and hermit crabs (it may feed on anything, but we take these as favourite foods). Now the dab will feed on shellfish, and the hermit crab on (say) small fishes or worms. The shellfish will feed on diatoms (among other things), and the small fish and worms perhaps on microcrustacea, and the latter on diatoms. Every chain of food animals in this sense terminates in the diatoms. If then it can be shown that these organisms are closely affected by hydrographic changes in the sea, we make a distinct step in proving the dependence of many biological phenomena on hydrographic ones. Now we are still far from possessing all the data necessary for proving this connexion, but I may refer to a most stimulating paper by Brandt, * which goes a long way in providing the information required. In the periodical cruises of the German International research vessel Poseidon samples of sea water were collected, and these were subsequently examined by the German chemists working under the International organization for the quantities of ultimate food-stuffs contained in them. The ultimate food-stuffs are nitrogen compounds (ammonia, nitrites, and nitrates), silicic acid, phosphates, and some other substances. It is upon these that diatoms (and consequently all other life in the sea) depend. The amount of nitrogen, in the above form, in the sea is very small (not more than about 0.2

* Brandt, Rappts. et Proc.-verb., vol. iii. app. D, 1905. 
parts in one million parts of sea water). It is small because it is continually being utilized as food by the diatoms; otherwise, being continually added to the sea by the decomposition of dead animals and plants, and by drainage from the land, the former would gradually become poisoned by it. The German analyses have shown that this small proportion of fixed nitrogen is not constant. Silica (which is required for the skeletons of the diatoms) and phosphates (which are similarly required for other organisms) are also present in correspondingly small and variable amounts.

Now it is of extreme interest to find that the amount of these ultimate food substances present in the sea is greatest just before the time when the maximum abundance of diatoms occurs, and is least about the time of the minimum. This applies more particularly to the German determinations of silica, but no doubt is also true of the nitrogen compounds. In the winter these food-stuffs have been greatly stored up. Then in the spring, under the influence of the rise in temperature of the sea and the increased intensity of the sunlight, an immense diatom reproduction takes place. The result of this is again to reduce the proportion of the food-stuffs, and as a consequence we have the summer minimum of diatom abundance. Further accumulation of the food-stuffs during this period of relative sterility leads to the autumn diatom maximum. Probably denitrifying bacteria play a not inconsiderable rôle in producing these variable proportions of nitrates present in the sea. It is known that bacteria exist in the sea which have the power of reducing nitrates to nitrites, the latter to ammonia, and ammonia to free nitrogen. In the latter form nitrogen is, of course, unavailable as food for diatoms. Now it has been shown that these denitrifying bacteria are more active at a high than at a low temperature. In the summer, then, they act on the fixed nitrogen present in the sea and render this unavailable as food for diatoms. In the colder season they are less active, and fixed nitrogen accumulates. It is a surprising thing that the plankton is less abundant in warmer tropical seas, in spite of a higher temperature and better light, than in colder sub-Arctic waters. The explanation lies probably in the more intense action of denitrifying bacteria in those warm waters, whereby the foodstuffs for the plankton are reduced.

Such considerations suggest the close connexion between the lowly organized plankton organisms and hydrographic phenomena. But can the same connexion be shown to exist between changes in temperature and salinity of sea water, and the changes in the abundance of such highly organized animals as our food-fishes? These connexions are more difficult to establish. The changing abundance of fishes on the fishing grounds is expressed in our imperfect statistical systems, and 
these in the past have lent themselves badly to investigations of this kind. The official returns of fish landed were almost entirely useless, and it was necessary for the fishery research organizations to so organize returns of fish caught as to show the connexions we speak of. Such investigations as those of Fulton and Henking were alone suitable.

Nevertheless, the dependence of fish migrations on hydrographic changes in the sea was always a priori probable. For a fish in the sea the water is just such a medium as the atmosphere is for a migratory bird; and if we recognize that climatic changes were the main factors in determining the breeding seasons and migrations of birds, it was surely probable that changes in temperature, etc., in the sea affected the breeding seasons and migrations of fishes. We know how very intimately the period of incubation of a fish egg is determined by the temperature of the water in which it develops; and how the spawning periods themselves are variable with the temperature of the sea. It was just as reasonable to assume that fish migrations were also influenced by temperature at least. The International investigations are slowly accumulating instances of these connexions. Some such connexions were established before the beginning of these researches, but others are coming to light. Long ago Möbius and Heincke divided the fishes visiting the Baltic into "north fishes" and "south fishes." The north fishes have their homes in the Norwegian sea and the waters surrounding Iceland and Faeroe. The south fishes come from the temperate Atlantic. Möbius and Heincke noticed that the north fishes only visited the Cattegat during the first part of the year, and the south fishes during the latter part. Afterwards, when the hydrographic periodicity of the waters of the Skagerak, Cattegat, and Baltic was demonstrated, these migrations were correlated with the ebb and flow of the Atlantic stream. We have seen that during the latter part of the year warm Atlantic water accumulates in the depths of the Skagerak and sets up a warm undercurrent into the Baltic, which is at a maximum about the end of the year. The south fishes appear and travel with this undercurrent, which sets up changes in the fishery biology of the Baltic. Thus in the German fishery cruises of December, 1903, plaice and other flat-fishes, many of them spawning, were found in the southern Baltic in this warm undercurrent. On the other hand, flat-fishes were hardly at all found in this part of the Baltic in June and July, at which time the bottom was covered by the water of the cold undercurrent from the Skagerak, which enters the Cattegat in spring. The hake is a typical south fish, and we have seen that its capture in the North Sea is very inconstant and indicates a definite migration. In the latter area it arrives towards the end of summer with the incoming Atlantic stream; then it is relatively abundant. In the winter it disappears again. 
Again, in the Barentz Sea the fisheries depend on the Atlantic flooding. This was shown by the Russian Fishery Commission in 1902. Two kinds of water enter this area. In the winter water from the Atlantic stream enters it, rounding North Cape. With the entrance of this occurs a "vast immigration of food fishes," which have the character of south fishes, and fishing is then productive. In the spring this Atlantic stream subsides and Arctic water takes its place. The fisheries then cease, but still at this time the Atlantic stream is flowing past North Cape, and cod are still caught in quantity.

The bottom of the North Sea is a submarine plateau, which towards the north slopes down to the depths of the Norwegian sea. On this northern slope Atlantic water may be found at all times of the year, but at varying depths, according as the incoming stream waxes and wanes. On the bottom is cold Arctic water, and separating this from the overlying Atlantic water is a mixed layer, which contains relatively large quantities of fish, such as the ling and halibut. The Swedish fishermen set long lines on the portion of this slope towards Shetland. In the summer the mixed layer of water is nearer to the surface than in the winter, when the Atlantic stream is gathering volume. Just as this mixed-water stratum is nearer or further from the surface, so the fishermen move about so as to find it. In summer, when it is near the surface, they set their lines near Shetland in about 7j-100 fathoms. In autumn, when the growing Atlantic stream forces down the significant water layer further from the surface, they are obliged to go further north, that is, down the North Sea slope, in order to find it. The lines are then set at depths of 150-200 fathoms.

The connexion of the herring migrations with the hydrographic changes is now quite certain, though much research is still necessary. There is no doubt that the great summer herring fishery of the east coasts of Britain hangs, in some way, on the periodic flooding of the North Sea with Atlantic waters. The case of the winter herring fishery off the coasts of Sweden is, however, a clearer case of the connexion of hydrographic and fishery phenomena. The winter herring is a north fish, and does not inhabit Atlantic water, but rather the mixed "Bank water" of lower salinity. In the great herring years it has been found that the Atlantic water lay at considerable depths beneath the surface, and that on this warm dense water was a layer of Bank water which covered the coastal shoals and entered the fjords. In this layer the herring was always found. In December, 1896, there was an unusual flooding of the Skagerak with Atlantic water. The level of this had reached so high that only a thin layer of Bank water remained. In this year the winter herring fishery was a failure.

Much has been done by the International researches to establish NEW SERIES. VOL, vir. No. 5 . 
the connexion of the cod fisheries with the hydrographic changes. In the winter of 1902-3 the Atlantic stream in the Norwegian sea attained its maximum much later than usual. That is, the stream had a greater volume than usual in this winter, and much more warm Atlantic water entered the northern ocean than in previous years. Many climatic phenomena accompanied this greater accumulation of warm water; the ice border everywhere receded to the north and east. Barometric depressions and cyclonic storms were more numerous than usual, and the weather was wild and stormy. Biological phenomena were also occasioned; Atlantic plankton was found as far north as $70^{\circ} \mathrm{N}$., even among the drifting ice floes near Jan Mayen. The spawning period of the cod was greatly postponed, and the Lofoten cod fishery (which depends on spawning fish) was delayed for two months, and was a partial failure. The winter herring fisheries at Bergen and in the Skagerak also failed.

Quite recently too Schmidt has made some interesting observations on the cod fisheries off the coasts of Iceland. The island is surrounded by cold Arctic water, but on the south the Atlantic stream approaches it and flows, as the Irminger Current, along the north-west coasts. The cod spawns at the south of Iceland in the border region of the warm Atlantic stream and the cold littoral water, and the eggs are only found where the temperature of the water is over $5^{\circ} \mathrm{C}$. Having spawned, the cod go west and north-west, following the Atlantic stream, and in the summer there is a general movement of cod, herring, and fish fry along the north and east coasts of Iceland; the fisheries take the same course, always in the border region of the Atlantic and Arctic waters.

More instances of hydrographic-biological phenomena might be quoted from the International publications, but we have noticed the more striking cases. The question why this connexion exists must be left for future investigation, and will certainly only be solved by very laborious researches. One wonders that the minute differences of salinity such as exist in the sea, and the comparatively small temperature differences, should affect so notably the migrations of fishes. It is perhaps a possible explanation that it is the food of the fishes that is affected in some such manner as we have discussed in relation to the varying abundance of diatoms in the plankton, but it is also probable that the metabolic processes of the fishes themselves are affected by even these small variations in the watery medium in which they live. After all, climatic differences affecting ourselves are sometimes very subtle, and when expressed by the readings of meteorological instruments are just as small as those which we have been considering. 